\title{
Disruption of Target Interactions Prevents the Development of Enkephalin Immunoreactivity in Sympathetic Neurons
}

\author{
Sophia Tyrrell and Story C. Landis \\ Department of Neurosciences, Case Western Reserve University School of Medicine, Cleveland, Ohio 44106
}

We compared the development of enkephalin (Enk) expression in normal rats and rats in which target contact was transiently disrupted with 6-hydroxydopamine (6-OHDA). During the first 3 postnatal weeks, there was a striking increase in Enk immunoreactivity (-IR) in superior cervical ganglia (SCG) assayed by radioimmunoassay (RIA). This increase was correlated with the appearance of Enk-IR in postganglionic neurons. In the caudal region of the SCG, the proportion of Enk-IR neurons and their immunoreactivity increased until one-third of the neurons possessed Enk-IR between postnatal days (P) 14 and 21. After P21, the number of Enk-IR neurons and their immunofluorescence decreased. By 6 weeks, only occasional neurons possessed moderate Enk-IR. The increases in Enk-IR were correlated with increased ganglionic proenkephalin A mRNA detected by in situ hybridization. The decrease in IR after P21 was not, however, paralleled by a comparable decrease in proenkephalin A mRNA. To determine whether interactions between SCG neurons and their target tissues influence Enk expression, we disrupted them by treating neonatal rats with a single dose of 6-OHDA at PO. This treatment transiently reduced sympathetic fiber density in the submandibular gland, one target of Enk-IR neurons, over $90 \%$. Two weeks later, the fiber density in glands of treated animals was not different from control. Following 6-OHDA, the concentration of Enk-IR in SCG extracts and the number of Enk-IR neurons and their immunofluorescence intensity failed to increase. SCG from treated rats also contained fewer neurons with proenkephalin A mRNA. In contrast, the content of neuropeptide $Y$ (NPY) and the proportion of NPY-IR neurons were not decreased by 6-OHDA treatment. Our results indicate that the developmental history of Enk expression differs from that of other neuropeptides in rat sympathetic ganglia, suggesting that distinct mechanisms regulate the expression of individual neuropeptides. Further, they provide evidence that target contact during a critical period is important for the induction of Enk.

\footnotetext{
Received Nov. 1, 1993; revised Mar, 7, 1994; accepted Mar. 29, 1994.

We are indebted to a number of our colleagues for their assistance: Dr. Ross Payne for his untiring patience and assistance with the denervation and reinnervation analysis, Dr. Ruth Siegel with the in situ hybridization, and Drs. Richard Wagner and Said Amini with statistical analyses. We also thank Drs. Hong Zhang and Yi Sun for performing NPY RIAs; Drs. Alison Hall, Paul Henion, Mahendra Rao, Ruth Siegel, and Richard Zigmond for useful insights in numerous discussions; and Drs. Alison Hall, Ruth Siegel and Richard Zigmond for thoughtfully reading and commenting on the manuscript. These studies were supported by HD 25681 .

Correspondence should he addressed to Dr. Story C. Landis at the above address. Copyright (C) 1994 Society for Neuroscience $0270-6474 / 94 / 145708-14 \$ 05.00 / 0$
}

[Key words: neural crest, autonomic neurons, transmitter phenotype, neuropeptide expression, neurotransmitter plasticity]

Neurons often contain one or more neuropeptides in addition to classical neurotransmitters. Many of these peptides modulate the actions of classical neurotransmitters or other neuropeptides (for review, see Hokfelt, 1991). Adult rat sympathetic neurons may contain different neuropeptides including NPY, vasoactive intestinal peptide (VIP), somatostatin, neurotensin, Enk peptides, or calcitonin gene-related peptide (CGRP; Hokfelt et al., 1977; Schultzberg et al., 1979; Jarvi et al., 1986; Landis and Fredieu, 1986; Sasek and Zigmond, 1989). Individual neurons may have very different peptidergic phenotypes. For example, while only rare SCG neurons are VIP-IR (Hokfelt et al., 1977; Sasek and Zigmond, 1989) about $60 \%$ of SCG neurons are NPYIR (Jarvi et al., 1986). Furthermore, some neuropeptides, such as VIP and CGRP, are present in the same neurons while other peptides such as NPY and Enk are not colocalized (Landis and Fredieu, 1986; Kondo et al., 1988; Henion and Landis, 1993). Although we have some understanding of the localization and function of neuropeptides in mature sympathetic neurons, the developmental mechanisms that give rise to the differential expression of neuropeptides by individual neurons are incompletely understood.

One of the first steps toward understanding how diverse peptidergic phenotypes are generated is elucidating the pattern of peptide expression during normal development. Three neuropeptides present in sympathetic neurons, NPY, VIP, and somatostatin, have similar developmental patterns of expression. Immunoreactivity for these peptides is first evident in many or all neurons during embryonic development and appears to be progressively restricted to a subset as the animal matures (Katz et al., 1992; Tyrrell and Landis, 1994). A different developmental pattern has been reported for Met-Enk-Arg-Gly-Leu (Enk8), one of several peptides derived from proenkephalin A. Kondo and colleagues find that Enk8-IR appears in a small number of neurons in the caudal portion of the rat SCG after birth and that the proportion of neurons containing Enk8-IR increases until 2-4 weeks of age but by 8 weeks, no Enk8-IR is detected (Kondo et al., 1988). Soinila and colleagues, however, failed to detect a decrease in Enk8-IR in the SCG (Soinila et al., 1991a,b), and small numbers of Enk-IR neurons have been reported in the SCG of adult rats (Schultzberg et al., 1979; Domeij et al., 1991). To clarify the developmental pattern of Enk expression in normal sympathetic ganglia and obtain data for comparison with those of experimental studies in which target interactions were disrupted, we analyzed the expression of two peptides, methionine (M-) and leucine, (L-) Enk, which, 
like Enk8, are derived from proenkephalin A. With immunocytochemistry, radioimmunoassay, and in situ hybridization, we found a large, transient increase in Enk-IR in the caudal part of the SCG postnatally.

The acquisition of Enk-IR and proenkephalin A mRNA could be influenced by a variety of signals, including interactions with target tissues. Precedents exist for an instructive role of targets in neurotransmitter choice (Landis, 1990; Patterson and Nawa, 1993). Target tissues influence the classical neurotransmitter phenotype of sympathetic neurons (Schotzinger and Landis, 1988; Schotzinger and Landis, 1990; Schotzinger et al., 1994). Further, transplantation studies indicate that the acquisition of VIP-IR in the developing sweat gland innervation requires interaction with the appropriate target (Schotzinger and Landis, 1990) and that sweat glands can induce VIP-IR in neurons that would not normally express it (Stevens and Landis, 1990; Schotzinger et al., 1994). In the case of enkephalins, Enk-IR appears in postganglionic sympathetic neurons after most have contacted their targets and changes as terminal plexuses within targets are elaborated (Black and Mytilineou, 1976; Rubin, 1985). For example, in the submandibular gland, a target of many SCG neurons including those that contain Enk-IR (Kondo et al., 1988; Shida et al., 1991; Soinila et al., 1991a,b; Luebke and Wright, 1992), the density of tyrosine hydroxylase (TH)-IR fibers increases during the first weeks after birth and fibers become associated with salivary acini (Kondo et al., 1988).

We uscd the ncurotoxin 6-OHDA, which selectively damages the terminals of catecholaminergic neurons (Thoenen and Tranzer, 1968; Tranzer and Thoenen, 1968) and, therefore, interrupts neuron-target interactions, to examine the possible role of target tissues on specification and maintenance of the enkephalinergic phenotype. While multiple doses of 6-OHDA administered to neonatal animals over several days cause the death of sympathetic neurons (Angeletti and Levi-Montalcini, 1970; Angeletti, 1971; Jaim-Etcheverry and Zieher, 1971; Clark et al., 1972; Finch et al., 1973), single doses do not cause significant sympathetic neuron cell death and have been used previously to delay innervation of sweat glands (Stevens and Landis, 1988). Since 6-OHDA treatment destroys only nerve terminals, reinnervation can occur relatively rapidly. We found that a single low dose of 6-OHDA prevented the normal increase in Enk-IR and proenkephalin A mRNA in the SCG but it did not decrease immunoreactivity for NPY. These data are consistent with the notion that target contact is required for the induction of Enk expression during a critical period.

\section{Materials and Methods}

Animals and dissection. Pregnant Sprague-Dawley rats were obtained from Zivic Miller (Zelienople, PA) $2 \mathrm{~d}$ before parturition. Rat pups were killed by ether inhalation at the appropriate age and the tissues of interest dissected. The SCG is found at the bifurcation of the internal carotid artery and was dissected free of surrounding tissues. The submandibular and sublingual glands are located together directly under the skin and above the ventral neck muscles. Both were dissected and then distinguished during microscopic analysis. Since the sympathetic innervation of sublingual glands is sparse, denervation and reinnervation by THIR fibers was examined in submandibular glands.

Some rat pups were injected intraperitoneally with $25 \mathrm{mg} / \mathrm{kg} 6-\mathrm{OHDA}$ hydrobromide (6-OHDA; Sigma, St. Louis, MO) in $0.9 \%$ sodium chloride and $0.1 \%$ ascorbic acid on $\mathrm{P} 0$, while littermates were injected with the vehicle alone and served as controls. This single injection of 6-OHDA did not appear to affect the viability of sympathetic neurons; on gross inspection, ganglia from treated animals were equivalent in size to those from animals injected with vehicle. Furthermore, the size of neurons within ganglia was not appreciably different in the two groups of animals.
Table 1. Antisera utilized

\begin{tabular}{|c|c|c|c|}
\hline Antigen & $\begin{array}{l}\text { Species of } \\
\text { origin/ } \\
\text { conjugate }\end{array}$ & Dilution & Supplier \\
\hline \multicolumn{4}{|c|}{ Primary antisera } \\
\hline L-Enk & Rabbit & $1: 400$ & Incstar \\
\hline M-Enk & Rabbit & $1: 1000$ & Incstar \\
\hline M-Enk & Rabbit & $1: 1000$ & Peninsula \\
\hline NPY & Guinea pig & $1: 250$ & P. D. Henion, ${ }^{a}$ M. S. Rao ${ }^{b}$ \\
\hline $\mathrm{TH}$ & Mouse & $1: 500$ & Incstar \\
\hline
\end{tabular}

Secondary antisera

$\begin{array}{llll}\text { Rabbit } & \text { Biotin } & 1: 200 & \text { Amersham } \\ \text { Mouse } & \text { FITC } & 1: 500 & \text { Antibodies Inc. } \\ \text { Guinea pig } & \text { FITC } & 1: 100 & \text { Jackson } \\ \text { Avidin } & & & \end{array}$

Avidin Texas red 1:300 Amersham

a University of Oregon, Eugene, OR.

${ }^{b}$ CalTech, Pasadena, CA.

Radioimmunoassays. Ganglia were placed in $2 \mathrm{~N}$ acetic acid on ice immediately following dissection. Tissue was homogenized by sonication and then boiled for $5 \mathrm{~min}$. Samples were centrifuged for $2 \mathrm{~min}$ and the supernatant dried under vacuum and stored at $-70^{\circ} \mathrm{C}$ for subsequent assays. M-Enk-IR was assayed using an RIA kit (Incstar; Stillwater, $\mathrm{MN}$ ) following the protocol included with the kit. Protein assays were performed using the Micro BCA kit (Pierce; Rockford, IL) according to instructions. NPY content was assayed as previously described (Tyrrell and Landis, 1994). In each case, peptide content was normalized to protein content and is therefore expressed as concentration.

Immunocytochemistry. Tissue used for immunocytochemical analysis was fixed in $4 \%$ paraformaldehyde in $0.1 \mathrm{M}$ phosphate buffer at $\mathrm{pH} 7.4$. Postnatal rat pups were perfused through the heart with fixative for 10 min followed by an additional 50 min of postfixation at room temperature. In all cases, tissue fixation was followed by equilibration in $30 \%$ sucrose to cryoprotect the tissue. Ten-micrometer frozen sections were cut and mounted on gelatin coated slides. Sections were labeled by rinsing them in phosphate-buffered saline (PBS), preincubating in dilution buffer $(0.5 \mathrm{M}$ sodium chloride, $0.01 \mathrm{M}$ phosphate buffer, $3 \%$ bovine serum albumin, $0.1 \%$ sodium azide, $0.3 \%$ Triton $\mathrm{X}-100$ ) for $1 \mathrm{hr}$ and then incubating in dilution buffer containing $5 \%$ rat serum and primary antisera (Table 1). The slides were rinsed and the sections incubated with secondary antisera (Table 1 ) in dilution buffer with $5 \%$ rat serum. Peptide-IR was enhanced using secondary antibodies conjugated to biotin and followed by avidin-Texas red (Amersham, Arlington Heights, IL). The slides were rinsed and coverslipped with glycerol:PBS (1:1) containing $1 \% N$-propyl gallate (Sigma, St. Louis, MO; Giloh and Sedat, 1982). Some sections were incubated without primary antisera to control for nonspecific binding or cross-reactivity of the secondary antisera. In addition, the speciticity of L- and M-Enk antisera was confirmed by absorbing them with either M- or L-Enk protein $(40 \mu \mathrm{g} / \mathrm{ml}$; Peninsula, Belmont, CA) prior to use. When antisera were absorbed with the peptide they were directed against, almost all immunofluorescence was absent and when antisera were incubated with the enkephalin peptide against which they were not directed, immunofluorescence was not detectably reduced. Thus, the antisera used recognized distinct enkephalin peptides.

In situ hybridization. Tissue used for in situ hybridization was frozen in Tissue Tek (Miles Scientific, Naperville, IL) on dry ice immediately following complete dissection and sectioned at $10 \mu \mathrm{m}$. Sections were mounted on gelatin coated slides so that tissue thawed only momentarily and the slides stored at $-70^{\circ} \mathrm{C}$ until use. The proenkephalin $A$ probe was a 48 base oligonucleotide complementary to bases $388-435$ of the proenkephalin A mRNA (Yoshikawa et al., 1984). It was made using solid-phase synthesis on an Applied Biosystems DNA synthesizer and gel-purified. The probe was labeled on the 3' end using terminal deoxynucleotidyl transferase (Bethesda Research Labs, Gaithersburg, MD) and ${ }^{35} \mathrm{~S}$-deoxyadenosine $5 '-(\alpha$-thio)triphosphate (New England Nuclear, Boston, MA; Siegel, 1989).

In situ hybridization was performed as previously described by Siegel 


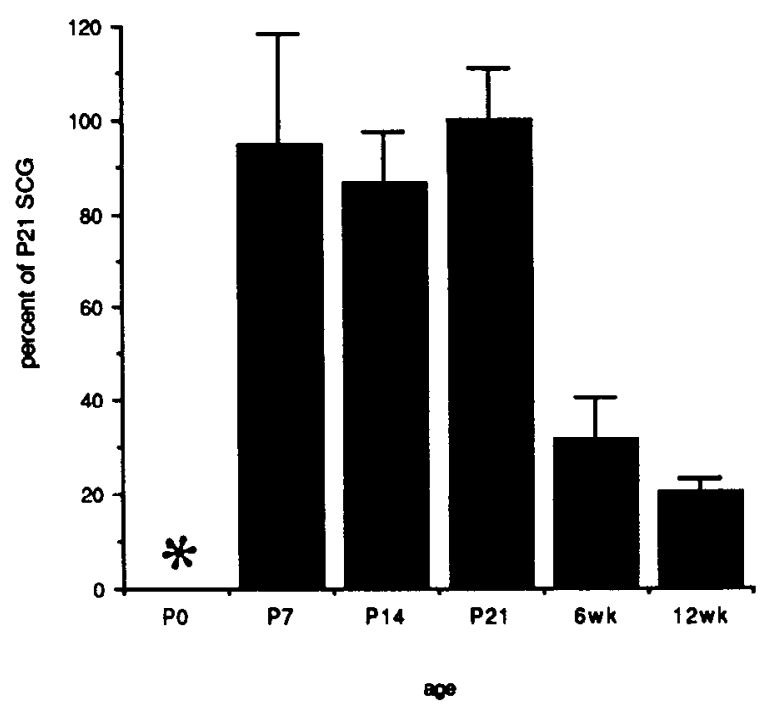

Figure 1. The concentration of M-Enk-IR in SCG extracts was transiently increased during postnatal development. M-Enk concentrations (pg M-Enk-IR/mg protein) were measured by RIA and compared to the concentration of M-Enk-IR in SCG extracts from P21 rats assayed at the same time. Four of five PO SCG extracts did not contain detectable M-Enk-IR, while the fifth extract contained an amount of M-Enk-IR that was just above the limit of detection ( $9 \%$ of the mean $\mathrm{P} 21$ value). Therefore, a mean concentration was not calculated for P0 SCG $\left(^{*}\right)$. In contrast, the concentration of M-Enk-IR was relatively high in SCG extracts from $\mathrm{P} 7, \mathrm{P} 14$, and $\mathrm{P} 21$ rats. Following P21, however, the concentration decreased. Values for P7, P14, and P21 are statistically different from 6 week and 12 week values (ANOVA, $p<0.0001$ ). The number of extracts assayed at each data point was three for all except P0 (five) and 12 wk (seven).

(1989). Briefly, slides were warmed to room temperature, fixed in $4 \%$ formaldehyde in $0.1 \mathrm{M} \mathrm{NaPO}_{4} \mathrm{pH} 7.2$ for $5 \mathrm{~min}$, rinsed in PBS, and incubated in $0.25 \%$ acetic anhydride for $10 \mathrm{~min}$. The slides were quickly rinsed in $2 \times$ SSC $(0.3 \mathrm{~m}$ sodium chloride, $0.03 \mathrm{~m}$ sodium citrate, $\mathrm{pH}$ 7; Sigma, St. Louis, MO), dehydrated through a graded series of ethanol and allowed to air dry. Once dry, the tissue was incubated in hybridization buffer [ $4 \times$ SSC, $50 \%$ formamide (Fisher, Fair Lawn, NJ), 500 $\mu \mathrm{l} / \mathrm{ml}$ sheared single-stranded DNA (Boehringer-Mannheim, Indianapolis, IN), $250 \mu \mathrm{l} / \mathrm{ml}$ yeast tRNA (Collaborative Research, Bedford, MA), $1 \times$ Denhardt's solution, and 10\% dextran sulfate (Sigma, St. Louis, MO)] without the probe for $1 \mathrm{hr}$. The sections were incubated overnight in hybridization buffer containing $7 \times 10^{5} \mathrm{cpm}$ of ${ }^{35} \mathrm{~S}$-labeled probe. Following hybridization, the slides were washed four times in $2 \times \mathrm{SSC}$, $50 \%$ formamide at $40^{\circ} \mathrm{C}$, twice in $1 \times \mathrm{SSC}$ at room temperature, briefly dipped in water to remove salt and allowed to air dry. Slides were dipped in Kodak NTB-3 liquid emulsion (Rochester, NY) diluted 1:1 with deionized water and dried for $2-3 \mathrm{hr}$. Slides were then placed in desiccated chambers and allowed to expose at $4^{\circ} \mathrm{C}$ for 6 weeks. They were developed using D-19 developer (Kodak, Rochester, NY), fixed in Kodak fixer (Rochester, NY), counterstained with cresyl violet, and examined using both bright- and dark-field microscopy.

The expression of proenkephalin A mRNA was analyzed by determining the percentage of neurons with grain densities above background levels and by measuring those densities. The percentage of postnatal neurons with proenkephalin A mRNA was determined by counting the total number of neurons in sections through different regions of the ganglia. The number of neurons with grain densities above background was determined and their percentage calculated. Grain densities were measured using the Cue 4 image analysis system (Olympus, Overland Park, KS). Specific grain densities were calculated by subtracting the background, or mean number of grains per unit area over a region of the ganglion without neurons plus one standard deviation from the grains per unit area over neurons. Sections from the same P14 SCG were processed simultaneously with each experiment and grain densities were normalized by comparing the average density of over control and 6-OHDA-treated adult SCG to the average specific grain density over neurons in this P14 ganglia.
Denervation/reinnervation analysis. The extent of sympathetic denervation and reinnervation was determined in submandibular glands from 6-OHDA-treated and vehicle-treated animals on P2, P7, P14, and $P 21$. Sections of submandibular glands from perfused rats were labeled with an antiserum directed against TH and the label visualized using a goat anti-rabbit antibody conjugated to rhodamine. Sections were examined using a $20 \times$ objective and images of these sections were captured via a SIT camera and saved on an optical disk for later analysis. When the images were recalled for analysis, a $100 \mu \mathrm{m} \times 100 \mu \mathrm{m}$ grid was placed over them and the number of intersections of TH-IR fibers with the grid counted. The fibers at these intersections were identified as those associated with gland parenchyma or those associated with blood vessels or nerve bundles in connective tissue. Data from each gland were averaged and expressed as a percentage of the mean value for glands from vehicle-treated animals at each age.

Several measures were taken to ensure that the sampling was representative of the entire gland. Images from at least three sections located a minimum of $300 \mu \mathrm{m}$ apart within the intact gland were analyzed. All fields that were completely or almost completely filled with glandular tissue were saved for analysis. Although examination of fields that were not entirely filled with glandular tissue resulted in some variation in the tissue area within individual fields, it allowed the edges of the tissue sections to be analyzed. Such areas included the region where the submandibular nerve enters the gland, where most TH-IR fibers were located at short survival times. All images were saved in the order they were encountered if one scanned the section from side to side and then top to bottom. The number of images acquired varied according to the size of the gland and the orientation in which it was sectioned. Depending on the number of saved images, every image, every other image, or every third image was analyzed. Between 17 and 68 fields were analyzed from each gland.

\section{Results}

\section{Enkephalin expression in sympathetic ganglia during normal development}

Enkephalin immunoreactivity. The concentration of M-Enk-IR in the SCG changed dramatically during postnatal development. At P0, SCG extracts from four of five animals lacked detectable levels of M-Enk while the concentration of M-Enk-IR in the extract from the fifth animal was just above the limit of detection (approximately $9 \%$ of the P21 value). Extracts of P7 SCG contained relatively high concentrations of M-Enk-IR and similar concentrations were present in extracts from P14 and P21 SCG. M-Enk-IR was still detectable in SCG extracts from 6 week old animals but its concentration was severalfold lower than in P21 SCG extracts; this decrease was statistically significant (ANO$\mathrm{VA}, p<0.0001)$ and the concentration of M-Enk-IR remained low in SCG extracts from older animals (Fig. 1).

Immunocytochemical localization of Enk-IR within the SCG revealed substantial changes in both $\mathrm{M}$ - and L-Enk-IR in neuronal cell bodies after birth. Since the pattern of immunoreactivity for both enkephalin peptides was similar at all ages, the term Enk will be used to refer to both peptides. At P0, no postganglionic neurons contained detectable Enk-IR; a moderately dense plexus of Enk-IR fibers, however, was present in the rostral third of the ganglion. Many of these fibers surrounded postganglionic neuronal cell bodies and are likely to be preganglionic in origin since in adult rats they disappear after section of the cervical sympathetic trunk (Henion and Landis, 1993). By P2, occasional Enk-IR postganglionic neurons were present in the SCG and their number and the intensity of their immunofluorescence subsequently increased (Figs. 2, 3). Enk-IR neurons were found predominantly in the caudal portion of the SCG as previously described (Kondo et al., 1988; KanagawaTerayama et al., 1989; Henion and Landis, 1993) and were not associated with Enk-IR fibers at any age. The percentage of neurons containing detectable Enk-IR was greatest between P14 

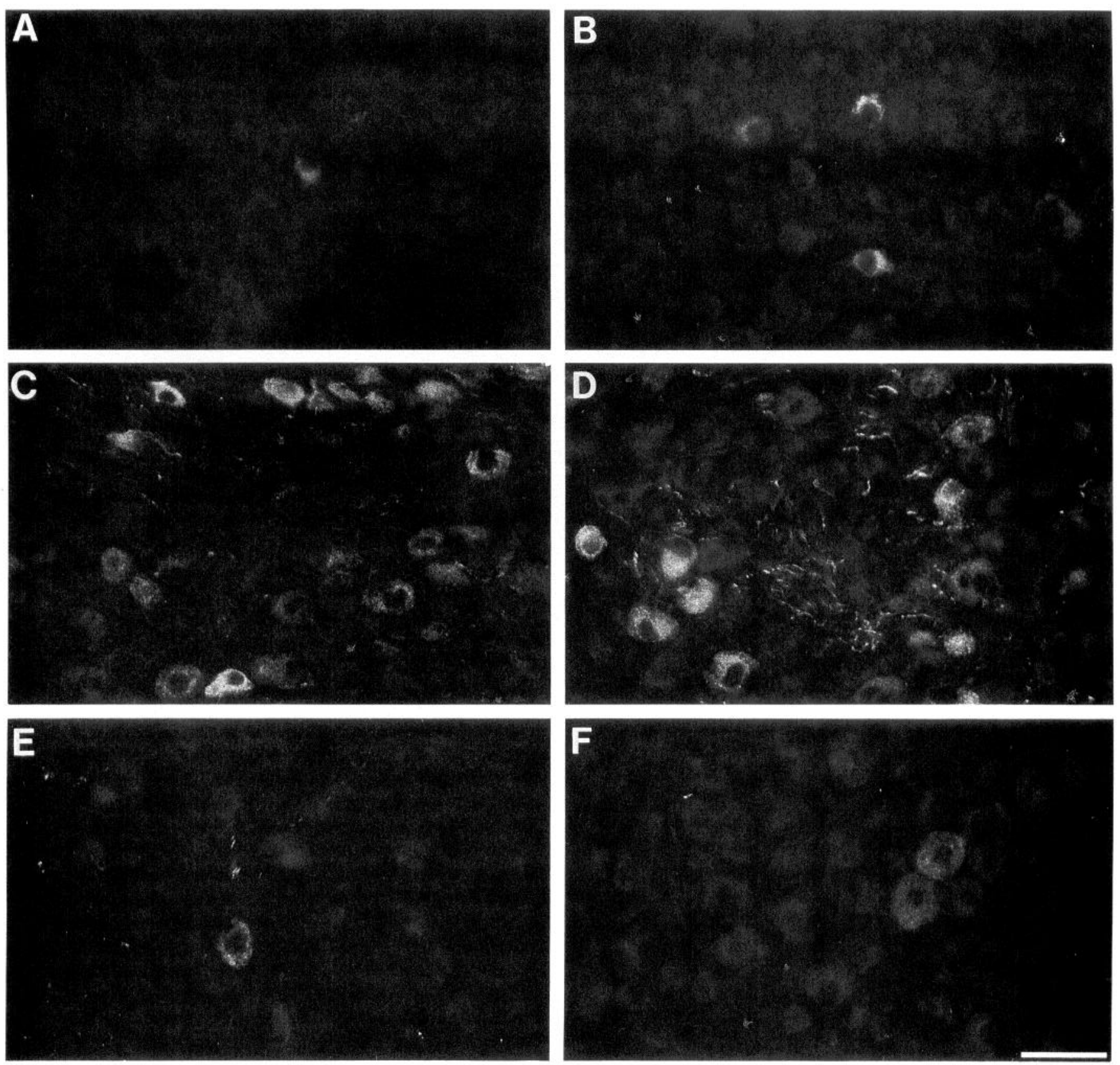

Figure 2. M-Enk-IR neuronal cell bodies appeared in the caudal portion of the SCG postnatally and their proportion changed with development. M-Enk-IR fibers were present in the rostral part of the SCG throughout postnatal development. M-Enk-IR neuronal cell bodies, however, were first detected in a small number of neurons in the caudal portion of the SCG at P2 $(A)$. By P7 $(B)$, the proportion and the immunofluorescence intensity of M-Enk neurons had increased. The proportion of immunoreactive neurons was greatest at P14 $(C)$ and P21 $(D)$. By P28 the proportion and the immunofluorescence intensity of M-Enk-IR neurons had dramatically decreased $(E)$ and at 6 weeks of age, only occasional M-Enk-IR neurons were detected $(F)$. Scale bar, $50 \mu \mathrm{m}$.

and P21, when approximately one-third of principal neurons in the caudal part of the SCG were Enk-IR. Even at this age when Enk-IR was highly expressed in the caudal region of the SCG, only a small number of neurons in the rostral portion of the ganglion were Enk-IR. While in the neonate Enk-IR fibers were mostly confined to the rostral SCG, at P14 and P21 immunoreactive fibers were also present in the caudal part. Since immunoreactive processes could be traced from neuron cell bodies and immunoreactive fibers were present in the external carotid nerve, which contains postganglionic axons, at least some of these fibers appear to be postganglionic axons.
After P21, there was a striking reduction in Enk-IR in postganglionic SCG neurons (Figs. 2, 3). At 4 weeks of age, far fewer immunoreactive neurons were detected and the immunofluorescence intensity of the remaining Enk-IR neurons had decreased. The loss of immunoreactivity continued into adulthood; at 6 weeks of age, occasional neurons exhibited moderate immunofluorescence and at 12 weeks of age only a small number of weakly immunoreactive neurons were detected. In contrast to the dramatic reduction in Enk-IR within postganglionic neurons, the dense network of Enk-IR fibers in the rostral SCG remained intensely immunofluorescent. 

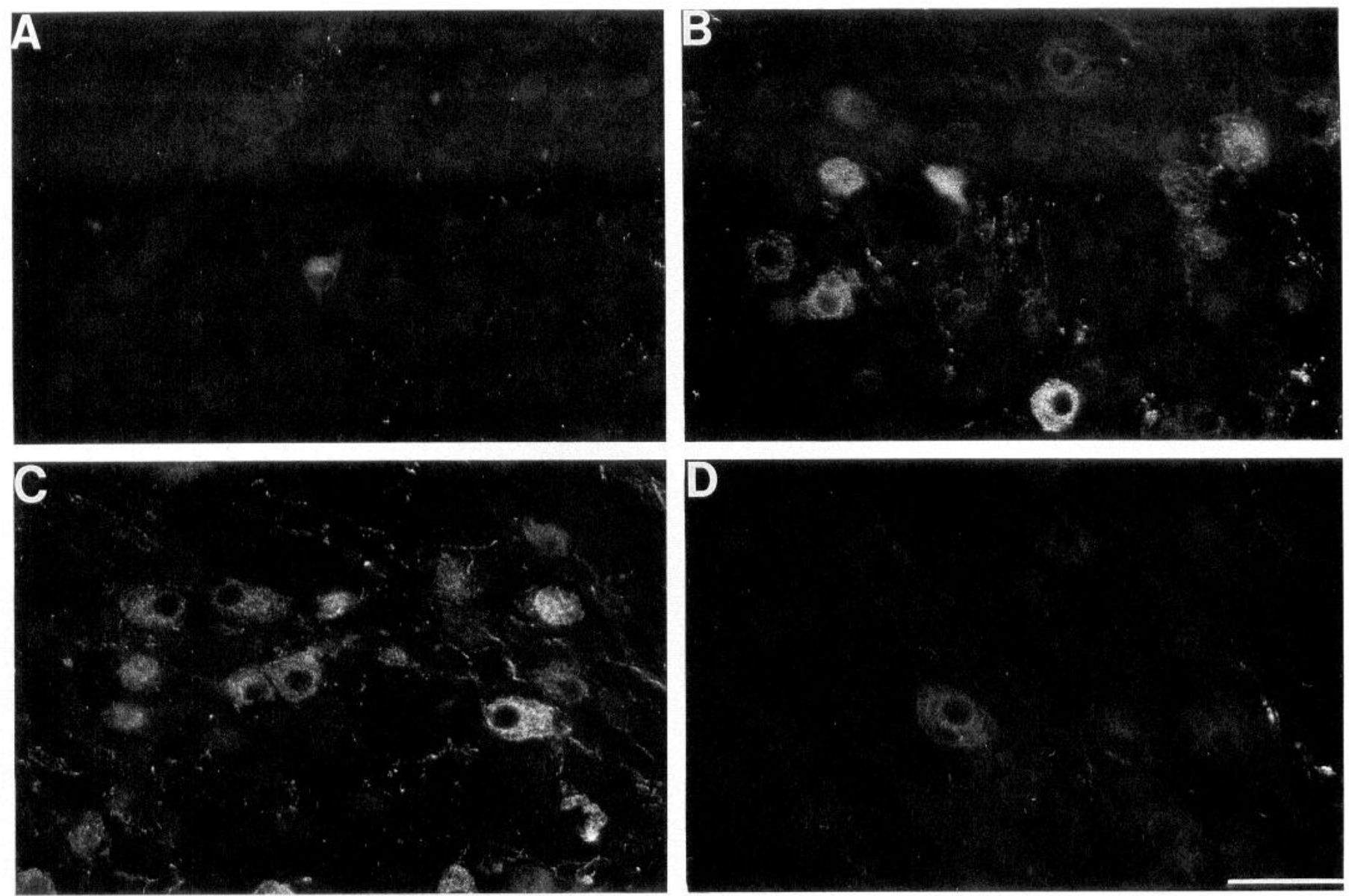

Figure 3. L-Enk-IR neuronal cell bodies appeared in the caudal portion of the SCG postnatally and their proportion changed with subsequent development. Many L-Enk-IR fibers were present in the rostral third of the SCG throughout development. In addition, faint L-Enk-IR was detected in a small number of neurons in the caudal region of the SCG at P2 $(A)$. By P14 $(B)$, both the proportion and the immunofluorescence intensity of these neurons had increased. At P21 $(C)$ approximately one-third of the neurons in the caudal part of the SCG were L-Enk-IR. After P21, the proportion of Enk-IR neurons and their immunofluorescence intensity declined rapidly. At 6 weeks of age, only occasional moderately L-Enk-IR and some faintly L-Enk-IR neurons were detected in the caudal part of the SCG $(D)$. Scale bar, $50 \mu \mathrm{m}$.

Proenkephalin $A m R N A$. In situ hybridization with a probe complementary to rat proenkephalin A mRNA was used to examine the distribution of the mRNA encoding M- and L-Enk in the SCG. At P1 and P2, a small percentage of neurons possessed grain densities above background levels (Figs. 4, 5). The propurtion of neurons with specific grain densities increased over the next 3 weeks. As was the case for Enk-IR, the majority of neurons with detectable proenkephalin A mRNA were located in the caudal region of the SCG. After P21 the proportion of neurons with detectable proenkephalin A mRNA appeared to stabilize since it was not significantly different in SCG from P21 and adult animals. In addition to determining the percentage of cells with detectable proenkephalin A mRNA, we counted the number of grains per unit area over individual cells and saw significant changes in the average densities with age. We found that the average specific grain density over individual cells increased until P14 and then decreased until it was equivalent to the density over P7 SCG neurons (Fig. 5).

\section{Effects of 6-OHDA treatment}

Denervation and reinnervation of the submandibular gland. Rats pups were injected on the day of birth with a low dose of 6-OHDA $(25 \mathrm{mg} / \mathrm{kg})$ or vehicle. Two days later, the overall density of
TH-IR fibers in the submandibular gland was reduced by $93 \%$ in comparison to the density in glands from littermates. In control animals, most TH-IR fibers were in the gland parenchyma and the density of these fibers was reduced by $97 \%$ in the 6-OHDA-treated animals (Figs. 6, 7). Most of the fibers remaining were close to the entry of the submandibular nerve. In contrast, the density of sympathetic fibers associated with blood vessels and in nerves coursing through the connective tissue was reduced by only $70 \%$ (Fig. 8 ), consistent with previous reports suggesting that blood vessel-associated fibers are relatively resistant to 6-OHDA treatment (Finch et al., 1972, 1973). Many of the TH-IR fibers in nerve bundles are likely to represent the preterminal axons of neurons whose terminals have been destroyed and they often possessed enlarged terminals resembling retraction bulbs of degenerating axons and growth cones of regenerating axons (Fig. 6). The differences in fiber density between glands from 6-OHDA- and vehicle-injected animals decreased with time (Fig. 7). By P7 many more TH-IR fibers were present and enlarged terminals were no longer common. Two and three weeks after 6-OHDA treatment, the submandibular glands contained approximately the same density of THIR fibers as control glands. At 3 weeks, however, the density of TH-IR fibers associated with vasculature within glands from 

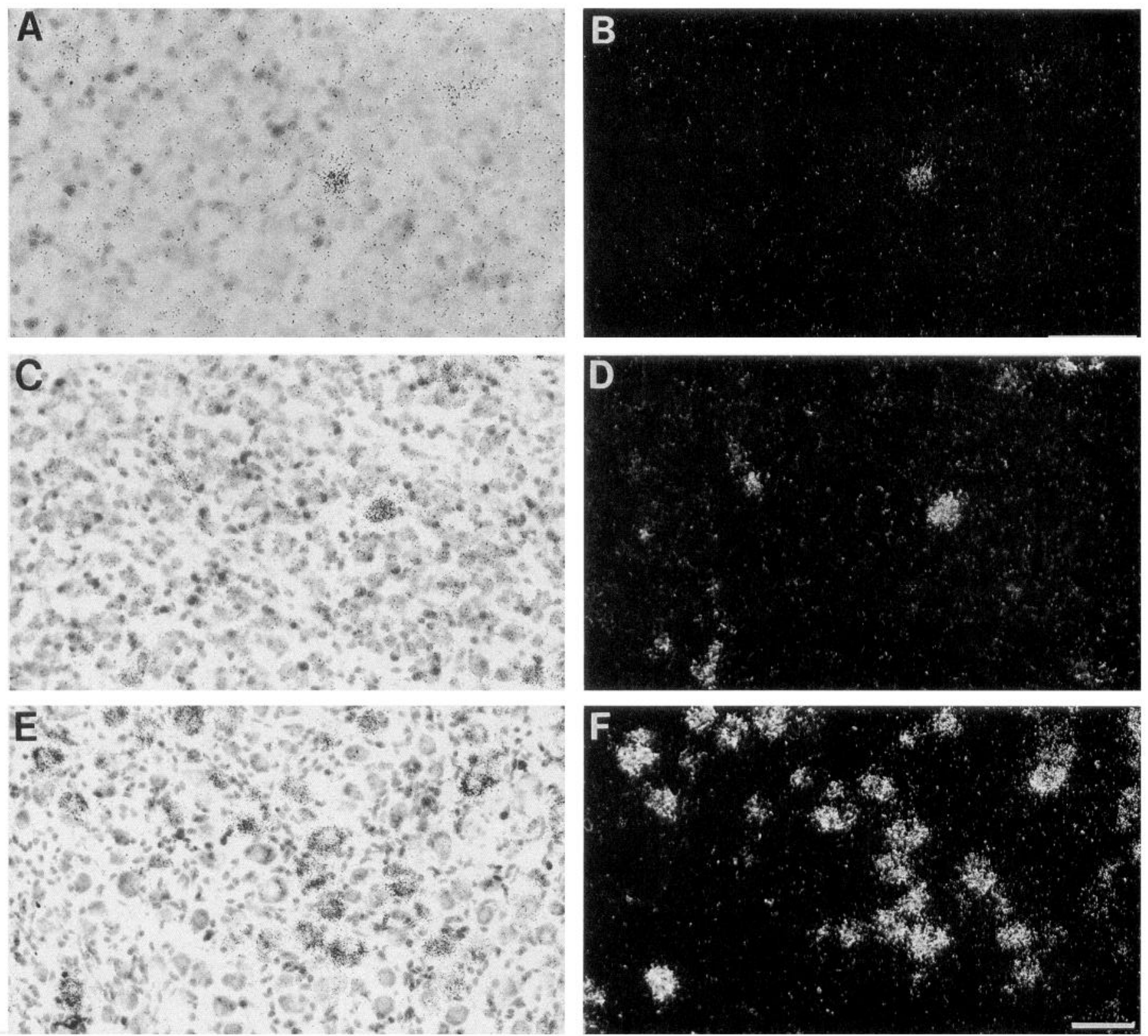

Figure 4. mRNA encoding the Enk precursor increased and then remained at high levels during postnatal development. An oligonucleotide probe complementary to proenkephalin A mRNA labeled with ${ }^{35} \mathrm{~S}$ was hybridized to sections of postnatal SCG. Grain densities above background were detected over a small number of SCG neurons at P1 using both bright-field $(A)$ and dark-field $(B)$ microscopy. By P7 the proportion of SCG neurons that specifically hybridized the probe had increased $(C, D)$ and this increase continued until P21 $(E, F)$. All sections shown were hybridized, incubated and developed at the same time. Scale bars, $50 \mu \mathrm{m}$.

6-OHDA-treated glands was greater than in control. Thus, the dose of 6-OHDA used in these studies allowed significant regrowth of sympathetic fibers over the course of several weeks.

Enkephalin peptides in SCG from 6-OHDA-treated animals. Enk-IR detected with radioimmunoassay or immunocytochemistry was reduced in the SCG of 6-OHDA-treated animals. At P7, P14, and P21 the concentration of M-Enk-IR in the SCG from 6-OHDA-treated animals was significantly less than in SCG from control animals (ANOVA, $p<0.0001$; Fig. 8) but it was the same in extracts from 6-7 week animals. Immunocytochemical analysis revealed a striking decrease in Enk-IR within postganglionic neurons but no difference was evident in the numerous Enk-IR fibers present in the rostral portion of the
SCG. Both the proportion of SCG neurons with Enk-IR and the intensity of that immunoreactivity were reduced (Fig. 9). This reduction was apparent at all ages examined ( $\mathrm{P} 7$ to 8 weeks of age) and was evident when ganglia from 6-OHDA-treated animals were compared to SCG from either untreated or vehicle-injected rats.

To determine if the reduction in Enk-IR was correlated with a change in proenkephalin A mRNA, we hybridized a radiolabeled probe complementary to proenkephalin A mRNA to sections of adult SCG from 6-OHDA- and vehicle-treated rats (Figs. 10,11). Both the proportion of neurons with specific grain densities and the mean grain density over labeled neurons were significantly reduced ( $t$ tests, $p<0.0001$ ). 
A.

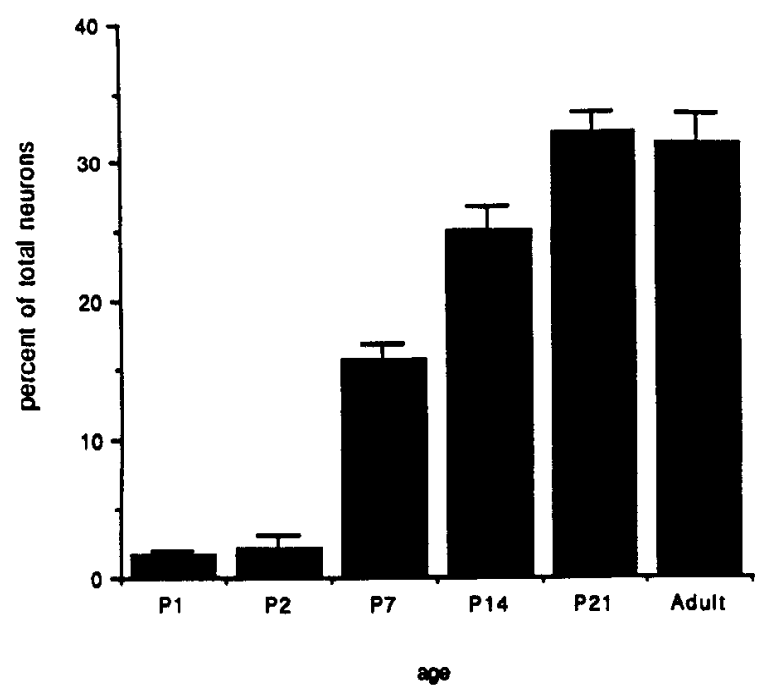

B.

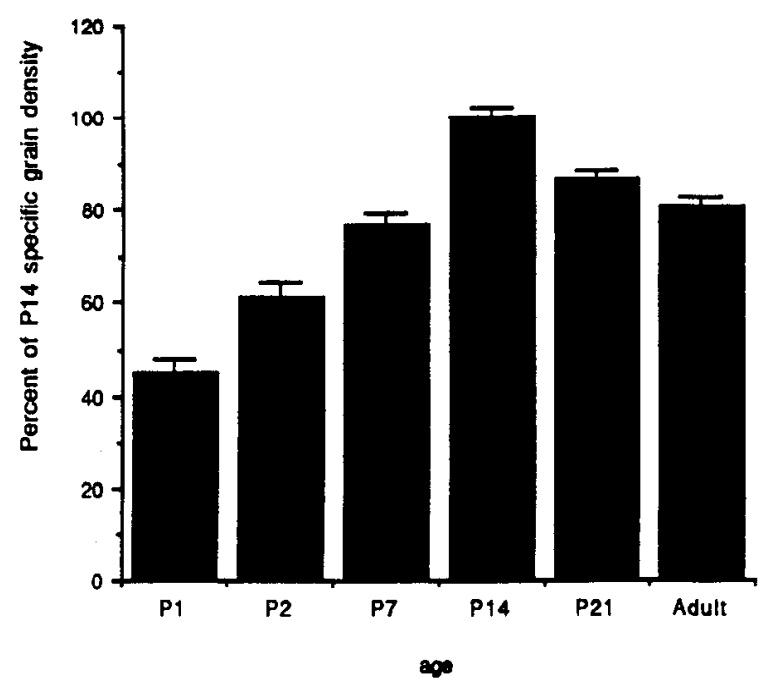

Figure 5. Proenkephalin A mRNA increased in the SCG during postnatal development. The percentage of neurons with grain densities above background indicating specific hybridization of the proenkephalin $A$ mRNA probe was determined $(A)$. This percentage increased during the first 3 postnatal weeks (ANOVA, $p<0.0001$ ), and most of these neurons were located in the caudal portion of the SCG. The number of ganglia for which percentages were determined was three for each time point $(P 1=7874$ neurons, $P 2=4322$ neurons, $P 7=3391$ neurons, $P 14=$ 8829 neurons, $P 21=7617$ neurons, adult $=6245$ neurons). The mean specific grain densities (grains/cell area) over SCG neurons to which the probe had hybridized were determined $(B)$ and found to significantly increase during the first two postnatal weeks (ANOVA, $p<0.0001$ ) Following P14, grain densities declined (ANOVA, $p<0.0001$ ). All values were significantly different from each other except for the $P 7$ and adult values (Fisher test, $p<0.05$ ). The number of neurons over which grain densities were determined are as follows: $P 1=90 ; P 2=60 ; P 7$ $=223 ; P 14=407 ; P 21=394 ;$ adult $=294$. SCG sections from three different animals were assayed for cach age.
Neuropeptide $Y$ immunoreactivity in sympathetic neurons from 6-OHDA-treated rats. When NPY-IR was examined in sections of SCG, ganglia from treated and untreated animals were indistinguishable (Fig. 12). In normal rats approximately $60 \%$ of SCG neurons were NPY-IR throughout postnatal development and NPY-IR was, for the most part, intense. Neither the proportion of neurons with NPY-IR neurons nor the intensity of NPY-IR appeared to differ in 6-OHDA- and vehicle-treated animals at any of the ages examined (P7, P14, P21, 6-7 weeks of age). Consistent with these immunocytochemical observations, when the concentration of NPY in extracts of treated and control P14 and P21 rats was compared, no difference was evident at P14 and the concentration was slightly increased in ganglia from treated rats at P21 (Fig. 13).

\section{Discussion}

The developmental pattern of Enk expression contrasts with that described for other neuropeptides found in rat sympathetic ganglia. NPY, VIP and somatostatin appear in a large proportion of ncurons during cmbryogenesis: NPY is first detected at E12.5, VIP at E14.5, and somatostatin is present at E16.5 (Katz et al., 1992; Tyrrell and Landis, 1994). In contrast, immunoreactivity for two enkephalin peptides, $M$ - and L-Enk, and mRNA for their common precursor first appeared in a small number of postganglionic SCG neurons after birth. During the first 3 postnatal weeks, the concentration of M-Enk-IR, the proportion of neurons with Enk-IR, the intensity of that immunoreactivity and the percentage of neurons containing proenkephalin A mRNA increased substantially in the SCG. After P21 the concentration of M-Enk-IR, the proportion of neurons with Enk-IR and the intensity of that immunoreactivity decreased. Between P21 and adulthood the percentage of SCG neurons with detectable proenkephalin A mRNA, however, was not altered.

The pattern of Enk-IR development in sympathetic neurons resembles that of Enk-IR in adrenal chromaffin cells, which, like sympathetic neurons, arise from the sympathoadrenal lineage (Landis and Patterson, 1981; Anderson, 1986, 1989, 1993; Anderson et al., 1991). Enk-IR in the adrenal gland transiently increases but then rapidly decreases (Cheung, 1989; Henion and Landis, 1990; Martinez et al., 1991). The timing of Enk expression in the two cell types, however, differs. In the adrenal gland, Enk-IR appears at E16, the proportion of Enk-IR cells peaks at E20 and then decreases to adult levels by P2 (Henion and Landis, 1990). Based on the temporal correlation between the onset of glucocorticoid production by the adrenal cortex and Enk expression in chromaffin cells, glucocorticoids were suggested to induce Enk-IR in vivo (Henion and Landis, 1990; Henion and Landis, 1992). Consistent with this notion, dexamethasone, a synthetic glucocorticoid, increases L-Enk-IR in chromaffin cells developing in culture (Henion and Landis, 1992). Glucocorticoids also influence Enk expression in adult SCG; L-Enk-IR is reduced in the SCG following adrenalectomy and it is increased after treatment with dexamethasone (Henion and Landis, 1993). While circulating glucocorticoids may contribute to the regulation of Enk-IR in SCG neurons, it seems unlikely that they are solely responsible for induction during development. While all sympathetic ganglia would in principle be exposed to similar glucocorticoid concentrations, Enk cxprcssion differs in individual sympathetic ganglia. For example, while significant increases in Enk-IR occurred in the SCG, no such increases were observed in the stellate ganglion, which contains 

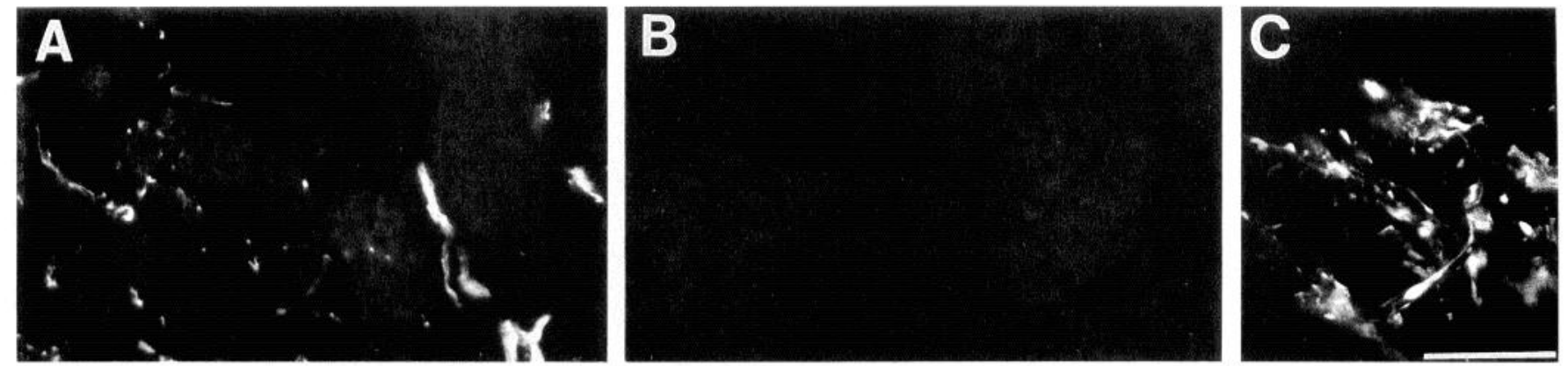

Figure 6. The submandibular gland parenchyma was denervated following 6-OHDA treatment. Many TH-IR fibers were present in the submandibular gland from a P2 control rat $(A)$. In contrast, most regions of submandibular glands from P2 rats that had been treated with 6-OHDA $2 \mathrm{~d}$ earlier lacked TH-IR fibers $(B)$. TH-IR fibers remaining in the parenchyma were close to the point where the submandibular nerve entered the gland $(C)$. Many of these TH-IR fibers possessed enlarged terminals, representing retraction bulbs or growth cones. Scale bar, $50 \mu \mathrm{m}$.

few Enk-IR neurons at any age (S. Tyrrell and S. C. Landis, unpublished observations). This difference suggests that other, more localized, factors also contribute to Enk expression.

One factor that might influence Enk expression in the SCG is interactions between neurons and the targets they innervate. Most neurons in the caudal part of the SCG project through the external carotid nerve (Bowers and Zigmond, 1979), and some of these, including Enk-IR neurons, innervate the submandibular gland (Kondo et al., 1988; Shida et al., 1991; Soinila et al.,

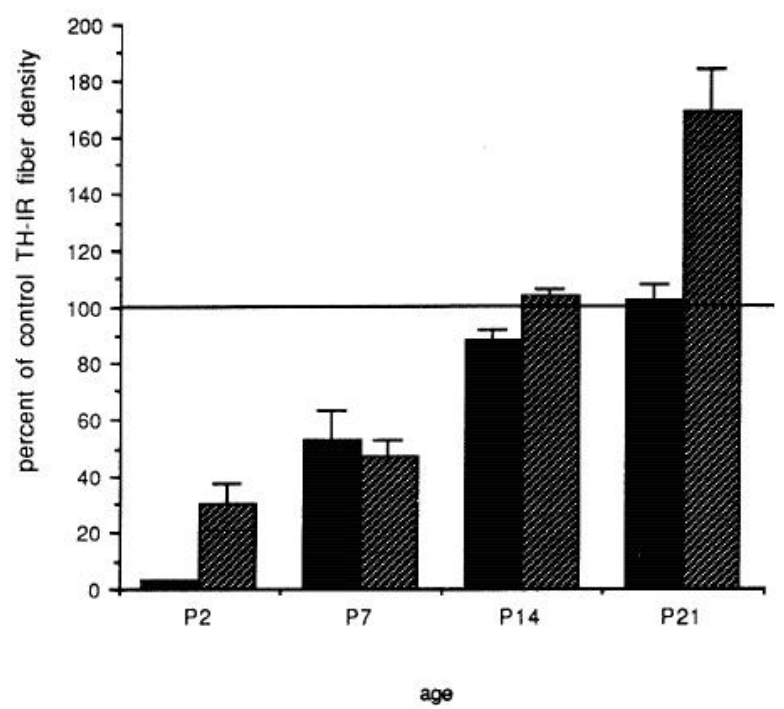

Figure 7. Following initial denervation, the density of TH-IR fibers in submandibular glands from 6-OHDA-treated rats increased. Neonatal rat pups were injected with $25 \mathrm{mg} / \mathrm{kg} 6-\mathrm{OHDA}$ intraperitoneally and the density of TH-IR fibers in the submandibular glands examined at various times after treatment. TH-IR fibers were identified according to the structures with which they were associated. The density of fibers associated with the glandular parenchyma is represented by solid bars, while the density of fibers associated with the vasculature or in nerve bundles coursing through the connective tissue is represented by hatched bars. Two days after 6-OHDA treatment, the density of parenchymal fibers was reduced by $97 \%$, while the density of fibers associated with either the vasculature or the connective tissue was reduced by $70 \%$. During subsequent development, the density of fibers in both compartments increased. By P14 the density of TH-IR fibers in the glands of experimental animals was not statistically different from control values $(t$ test, $p=0.6)$. Submandibular glands from six $\mathrm{P} 2$ rats were analyzed; these animals were from three different litters that were treated separately. For all other ages, glands from three rats were analyzed and these animals were from two different litters that were injected separately. Error bars represent SEM in one direction only. 1991a,b). The development of the sympathetic innervation and differentiation of this gland coincides with the increase in Enk expression in the SCG. At P0 a sparse plexus of TH-IR and catecholamine fluorescent fibers are present in the developing submandibular gland (Kondo et al., 1988; Tyrrell and Landis, unpublished observations). Soon after this, at P1, proenkephalin A mRNA is first detected and by P2 Enk-IR cell bodies are present in the caudal region of the SCG. At P7 some TH-IR fibers are associated with the vasculature while others have become associated with acini and Enk-IR fibers are present (Kondo et al., 1988). At P14 and P28 there are numerous TH- and EnkIR fibers in inter- and intralobular connective tissue and associated with acini (Kondo et al., 1988; Tyrrell and Landis, unpublished observations). Since removal of the SCG results in the disappearance of TH-IR fibers and a significant reduction in the density of Enk-IR fibers, these fibers originate in the SCG

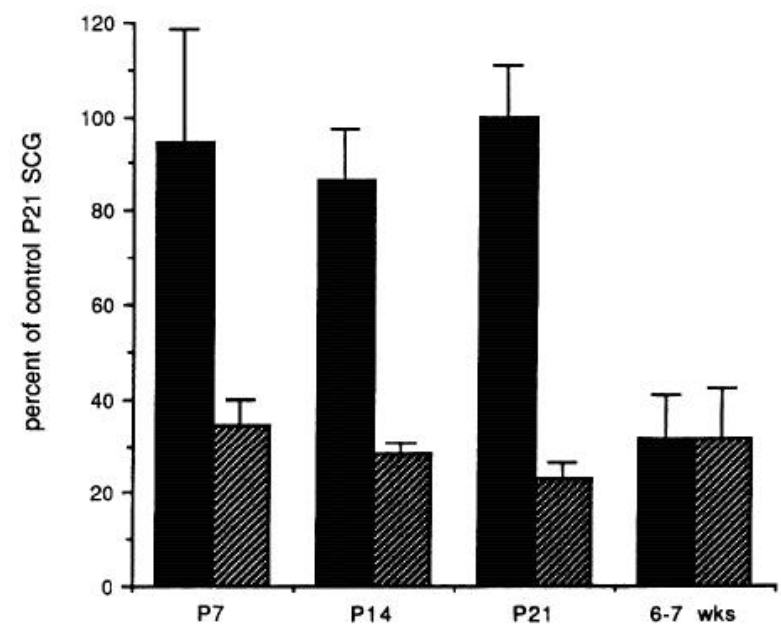

age

Figure 8. M-Enk-IR in SCG assayed using radioimmunoassay was reduced following 6-OHDA treatment. The concentration of M-EnkIR (pg M-Enk-IR/mg protein) in SCG extracts from 6-OHDA-treated animals (stippled bars) was significantly decreased relative to that in extracts from control animals (solid bars) over time (two-way ANOVA, $p<0.0001$ ). Extracts from both control and 6-OHDA-treated animals were assayed at the same time; the data from normal ganglia are also presented separately in Figure 1. There was no difference in the concentration of M-Enk-IR at 6-7 weeks of age ( $t$ test, $p>0.05$ ). Error bars represent SEM in one direction only. Three SCG extracts, made from ganglia from different animals, were assayed for all points except P14 and P21 for which four extracts were assayed. 

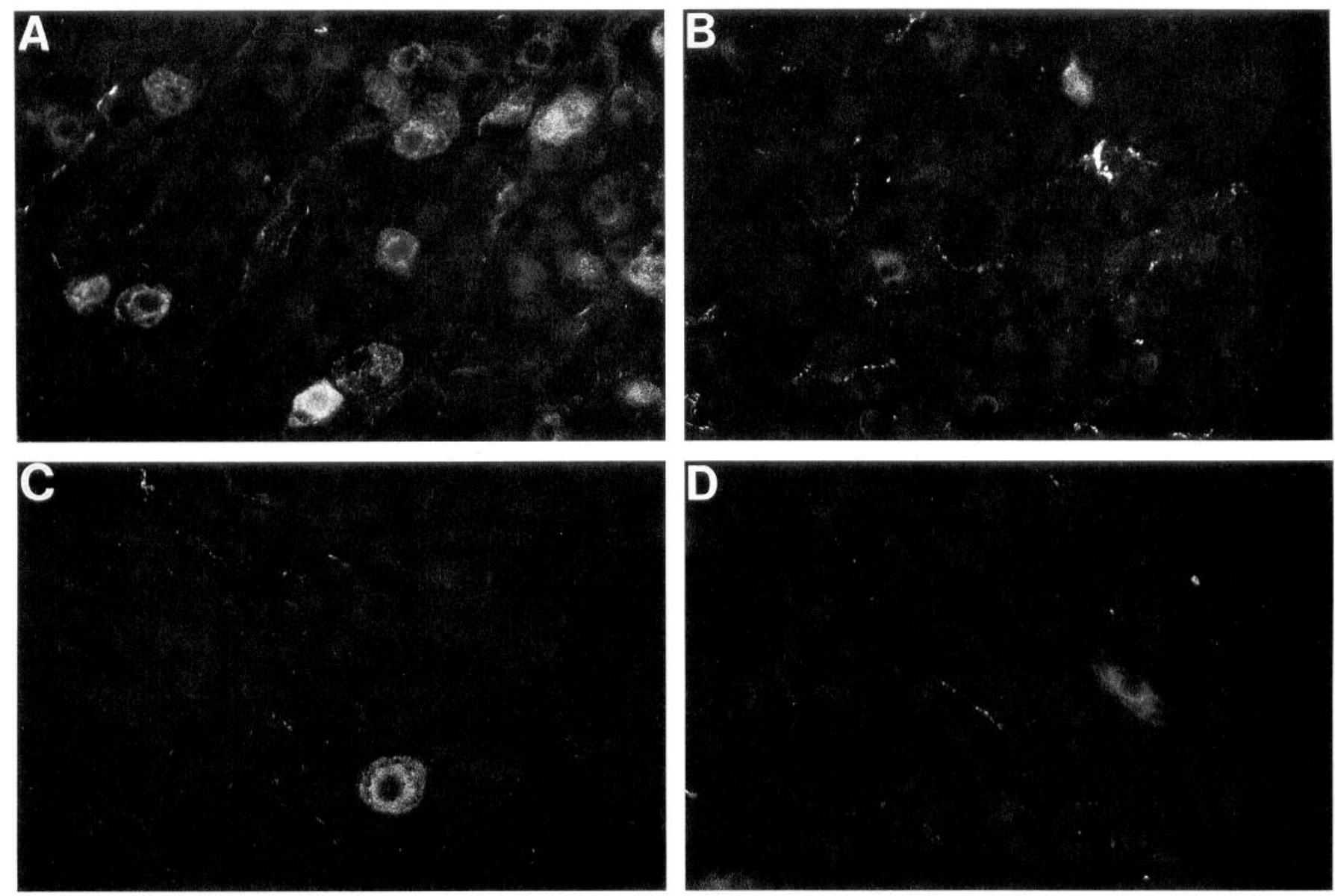

Figure 9. Enk-IR in SCG assayed using immunocytochemistry was reduced following 6-OHDA treatment. The developmental pattern of EnkIR in the SCG following vehicle injection was indistinguishable from that in SCG from untreated rats. At P14 numerous L-Enk-IR neurons were present in SCG from vehicle-injected rats $(A)$. Many fewer L-Enk-IR neuronal cell bodies were present in SCG from 6-OHDA-treated animals and the immunofluorescence intensity of L-Enk-IR in these neurons was reduced $(B)$. In SCG from adult animals, the number of Enk-IR neurons was reduced compared to SCG from younger animals. The proportion, however, of neurons with Enk-IR and the immunofluorescence intensity of that immunoreactivity were still greater in SCG from vehicle-injected rats $(C)$ than in 6-OHDA-injected rats $(D)$.

(Kondo et al., 1988; Shida et al., 1991; Soinila et al., 1991a). Targets of enkephalin-containing sympathetic neurons other than the submandibular gland remain to be defined.

To examine the possibility that targets influence Enk expression, we used 6-OHDA to axotomize sympathetic axons close to their target tissues. We injected 6-OHDA at P0, when sympathetic fibers had arrived at and begun to innervate the submandibular gland (Kondo et al., 1988; Tyrrell and Landis, unpublished observations). This resulted in a transient loss of target contact since 2 weeks after treatment the density of TH-IR fibers in the submandibular gland was indistinguishable from that in control glands. Since many TH-IR axons were present in submandibular nerve, it seems likely that the gland was reinnervated by fibers that would normally have innervated it.

The increase in Enk expression in the SCG of vehicle-injected rats was similar to that observed in normal animals but it was reduced in 6-OHDA-injected rats. Between $\mathrm{P} 7$ and P21, the concentration of M-Enk-IR in the SCG was significantly less in 6-OHDA-treated than in control rats and both the proportion of SCG neurons with Enk-IR and the intensity of that immunoreactivity was decreased in developing animals. Neither the density of Enk-IR fibers in the rostral SCG nor the intensity of Enk-IR within those fibers, however, was detectably altered suggesting that the decrease in Enk-IR was specific to postganglionic sympathetic neurons. The reduction in Enk-IR following 6-OHDA treatment did not represent a generalized decrease in neuropeptide expression or neuronal ill health since there was no difference detected in either the proportion or intensity of NPY-IR neurons in sympathetic ganglia from 6-OHDA- and vehicle-treated rats. Further, the concentration of NPY in SCG of treated and control rats was indistinguishable at P14 and slightly elevated, rather than decreased, in SCG of treated rats at P21. About $60 \%$ of SCG neurons are NPY-IR in normal rats (Jarvi et al., 1986) and none of these are Enk-IR (Kondo et al., 1988; Henion and Landis, 1993). At P14 and P21, the majority of neurons in the caudal region of the SCG from untreated rats lacking NPY-IR are Enk-IR. Since the proportion of NPY-IR neurons was unchanged, the absence of an increase in Enk-IR was unlikely to result from death of Enk-IR neurons. These data suggest that factors in the target are important in specifying the increase in Enk-IR that normally occurs during postnatal development.

The effects of 6-OHDA on Enk-IR within the SCG persist in the adult even after target contact has been reestablished. Both immunocytochemical and in situ hybridization histochemical studies revealed decreased Enk expression in SCG of adult rats 

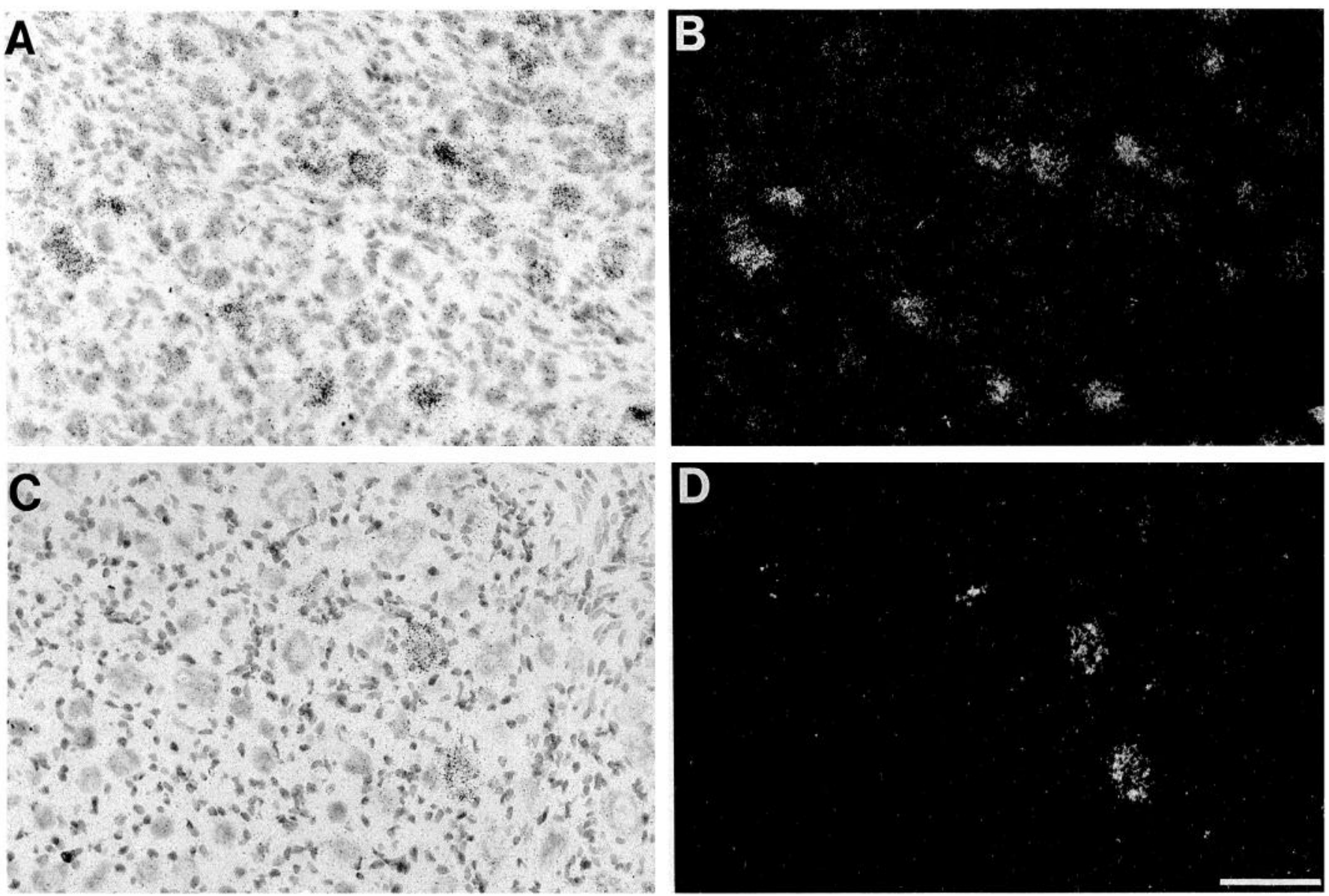

Figure 10. Proenkephalin A mRNA in SCG was reduced following 6-OHDA treatment. mRNA encoding the enkephalin precursor was assayed using in situ hybridization histochemistry. Cells possessing grain densities above background were considered to contain proenkephalin A mRNA. While a significant percentage of SCG neurons met this criteria as seen using both bright-field $(A)$ and dark-field $(B)$ microscopy in control adults, substantially fewer SCG neurons did in ganglia from adult rats treated with a single injection of 6-OHDA $(C, D)$. Scale bar, $50 \mu \mathrm{m}$.

following neonatal 6-OHDA treatment. These results suggest that the acquisition of Enk-IR is prevented and not simply delayed. A partial reduction in VIP-IR was also observed in the sweat gland innervation after delay of target innervation using 6-OHDA, although in those experiments, cross-innervation as well as reinnervation may have occurred (Stevens and Landis, 1988). Despite the difference in Enk-IR assayed by immunocytochemistry and proenkephalin A mRNA assayed by immunocytochemistry in adult rat SCG, we did not detect a difference in the concentration of M-Enk-IR by RIA. It is likely that this failure reflects the fact that most ganglionic Enk-IR in the adult is present in preganglionic fibers that did not appear to be affected by the treatment. Permanent reductions in peptide expression following interruption of target contact might occur if there was a critical period for target-dependent induction. Those neurons that contained Enk following 6-OHDA treatment might have contacted their targets and been induced to express these peptides prior to treatment. While a critical period for target-dependent induction could be intrinsic to the neuron, an alternative explanation for a critical period entails developmental changes in the target tissue. Salivary gland acinar cells proliferate and their phenotypes change between P0 and P20 (Schneyer and Hall, 1969; Redman and Sreebny, 1970; Cutler and Chaudhry, 1974; Srinivasan and Chang, 1977; Ball et al., 1984; Moreira et al., 1991). During acinar differentiation, mark- ers for the different types of acinar cells, proteins C and B1 change and tonin, phosphofructokinase and the sodium, potassium ATPase increase within the gland (Bhoola et al., 1973; Yamashina and Barka, 1974; Sahara et al., 1981; Zacharatos et al., 1983; Martinez and Camden, 1986; Camden and Martinez, 1987; Ball et al., 1988; Hamano et al., 1989; Moreira et al., 1991) and adrenergic receptors and epidermal growth factor appear in the glands (Ludford and Talamo, 1980; Cutler et al., 1981; Raaberg et al., 1988). Along with alterations in these properties, changes could well occur in the production of peptidergic factors; the target might have distinct effects on the expression of neuropeptides at different stages of development.

Enk-IR increased during the first weeks of postnatal development but decreased in neuron cell bodies after P21. While there was a correlation between Enk-IR and proenkephalin A mRNA during the first 3 postnatal weeks, the proportion of neurons with proenkephalin A mRNA did not decrease after P21 and there was only a small decrease in the amount of mRNA per neuron (see also Watanabe et al., 1991). Discrepancies in Enk protein and proenkephalin A mRNA have been reported previously (Livett et al., 1982; Kilpatrick et al., 1985, 1987; Pittius et al., 1985; Howells et al., 1986; Siegel et al., 1988; Stachowiak et al., 1988). The difference between the levels of Enk-IR and proenkephalin A in the adult could reflect increased stability of proenkephalin A mRNA, decreased translation of 

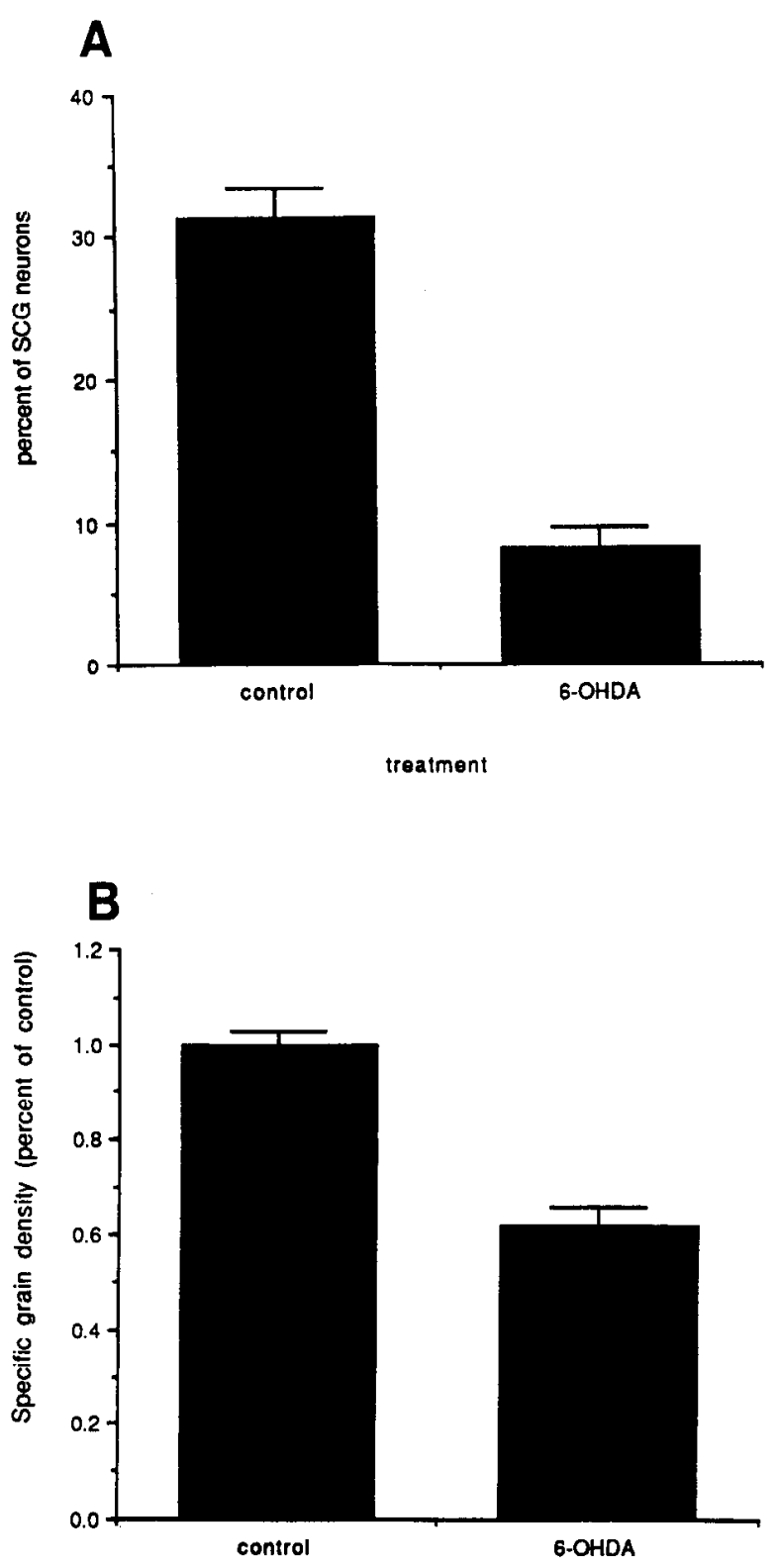

treatment

Figure 11. Less proenkephalin A mRNA was present in SCG from 6-OHDA-treated rats. The percentage of adult SCG neurons containing proenkephalin A mRNA was determined by counting the number of neurons with grain densities above background and the total number of neurons in the SCG following in situ hybridization of a probe complementary to proenkephalin A mRNA and autoradiography $(A)$. There was a significant reduction in the proportion of neurons with grain densities above background levels in treated rats relative to controls $(t$ test, $p<0.0001$ ). When the mean specific grain densities of positive neurons were determined, it was $60 \%$ less in neurons from 6-OHDAtreated animals than in neurons from control animals; this was a significant decrease ( $B ; t$ test, $p<0.0001)$. SCG from three control animals and six 6-OHDA-treated animals were analyzed to determine the percentage of neurons with grain densities above background; the mean specific grain densities were determined from SCG from three animals and are expressed as the percentage of control values. Raw data for control SCG is the same as that presented in Figure 6. The number of neurons analyzed are as follows: $A$, control $=3326$ neurons, 6 -OHDA -7952 neurons; $B$, control $=294$ neurons, 6-OHDA $=108$ neurons. In both graphs error bars represent SEM in one direction only. proenkephalin A mRNA, decreased processing of the proenkephalin A precursor, increased transport of Enk to the periphery, and/or increased degradation of Enk-IR. Precedents exist for decreased or incomplete processing of the Enk prccursor in brain (Birch and Christie, 1986; Spruce et al., 1990) and adrenal medulla (Birch and Christie, 1986; Stachowiak et al., 1988), including a developmental decrease in M-Enk-IR in adrenal glands (Coulter et al., 1990; Martinez et al., 1991). RIA analysis of adult bovine sympathetic ganglion extracts before and after enzymatic digestion suggest that only one-sixth of proenkephalin A is fully processed (Bastiaensen and de Potter, 1987). The functional consequences of decreased or partial processing of proenkephalin A are poorly understood but some intermediates in Enk processing may serve as neuropeptides in their own right (Davis et al., 1990).

The signals that regulate the decrease in Enk-IR remain to be defined. While the increase in Enk-IR is correlated with an increase in proenkephalin mRNA, the decrease in Enk-IR is not accompanied by a comparable decrease in proenkephalin $A$ mRNA. This suggests that the two changes in expression in Enk-IR are regulated at different steps in the biosynthetic pathway, suggesting that the decrease is not caused simply by loss of the inducing signal. Denervation of SCG neurons by sectioning the cervical sympathetic trunk causes a significant increase in the number and immunofluorescence intensity of EnkIR neurons (Henion and Landis, 1993). The effect of surgical denervation on Enk-IR is partially mimicked by treatment with the opiate antagonist naloxone (Henion and Landis, 1993) suggesting that Enk released from preganglionic fibers decreases Enk-IR in SCG neurons in vivo. It is unlikely, however, that enkephalinergic innervation is responsible for decrease that occurs after P21 since it is predominantly in caudal neurons in the SCG that are not innervated by enkephalin containing fibers.

The developmental mechanisms that regulate acquisition of the appropriate complement of neuropeptides by individual autonomic ncurons appcar to be complex. In rat sympathetic neurons, distinct developmental patterns of expression exist for different neuropeptides (Landis et al., 1988; Katz et al., 1992; Tyrrell and Landis, 1994) and multiple signals including some derived from target tissues appear to contribute to the generation of mature neuropeptidergic phenotypes. Progress is being made in identifying the molecules responsible for particular target effects on specific neuropeptides. For example, sweat glands induce VIP expression in sympathetic fibers and cell bodies (Schotzinger and Landis, 1990; Stevens and Landis, 1990; Schotzinger et al., 1994), and a candidate factor for mediating this induction that is distinct from cholinergic differentiation factor/leukemia inhibitory factor (CDF/LIF) and ciliary neurotrophic factor (CNTF) has been identified in extracts of rat footpads (Rao and Landis, 1990; Rao et al., 1992a, 1993; Rohrer, 1992; Masu et al., 1993). Choroid cells in the eye appear to induce somatostatin immunoreactivity in the ciliary neurons that innervate them and culture studies suggest that this effect is mediated by activin (Epstein et al., 1988; Coulombe and Nishi, 1991; Coulombe et al., 1993). In culture, neuropeptide expression by sympathetic neurons is altered by the cytokines, CDF/LIF and CNTF, which increase VIP-IR, substance P-IR, and somatostatin-IR, while decreasing NPY-IR (Ernsberger et al., 1989; Nawa and Patterson, 1990; Nawa and Sah, 1990; Friedin and Kessler, 1991; Nawa et al., 1991; Rao et al., 1992b; Fann and Patterson, 1993; Shadiack et al., 1993). Further, both CDF/LIF and CNTF increase proenkephalin A mRNA (Fann 

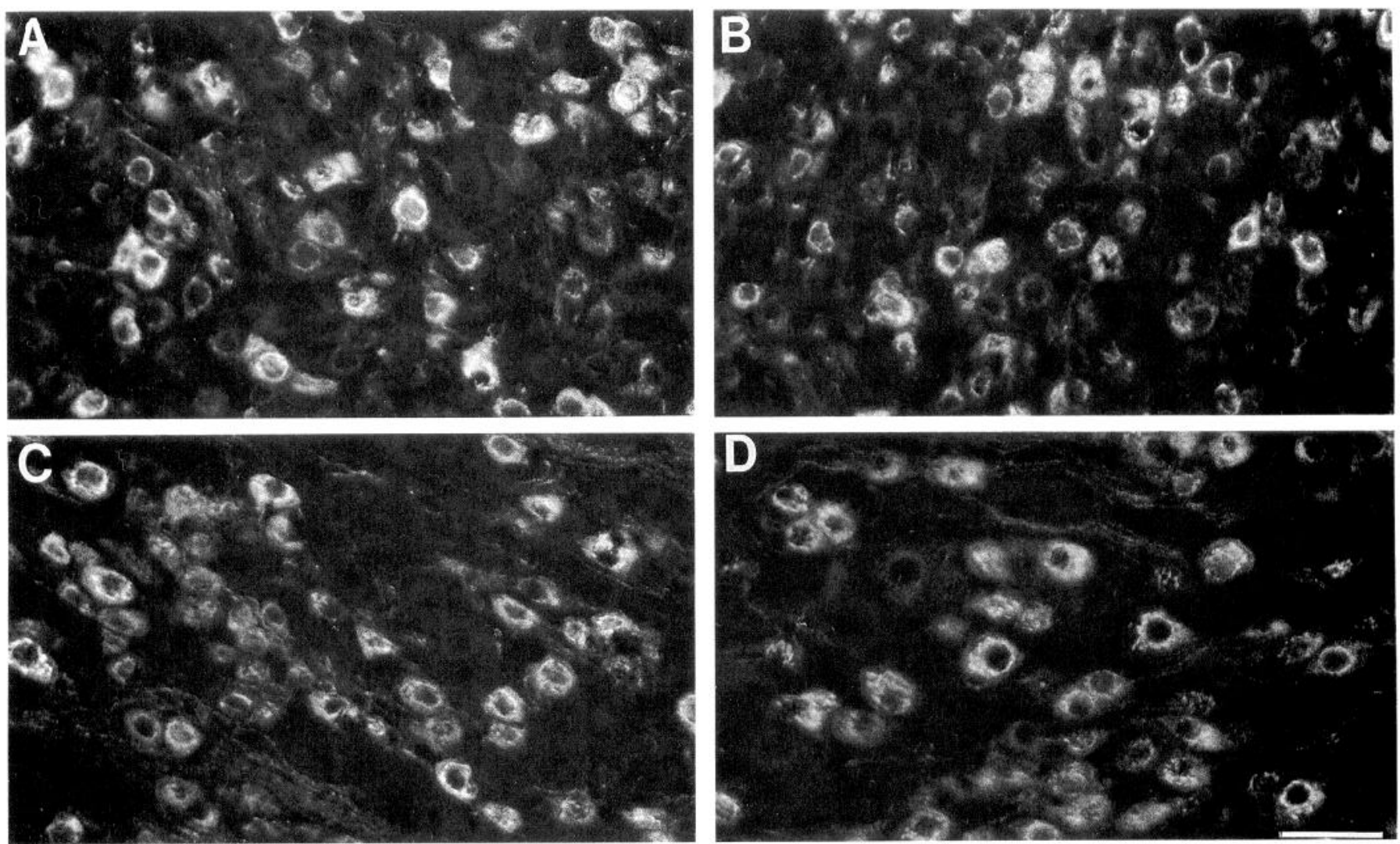

Figure 12. NPY-IR in SCG did not change following 6-OHDA treatment. Both the proportion and the intensity of NPY-IR cells appeared similar in SCG and stellate ganglia from treated and untreated rats. NPY-IR was present in approximately $60 \%$ of SCG neurons from control P7 ( $A$ ), treated P7 $(B)$, control P21 $(C)$, and treated P21 $(D)$ rats. Scale bar, $50 \mu \mathrm{m}$.

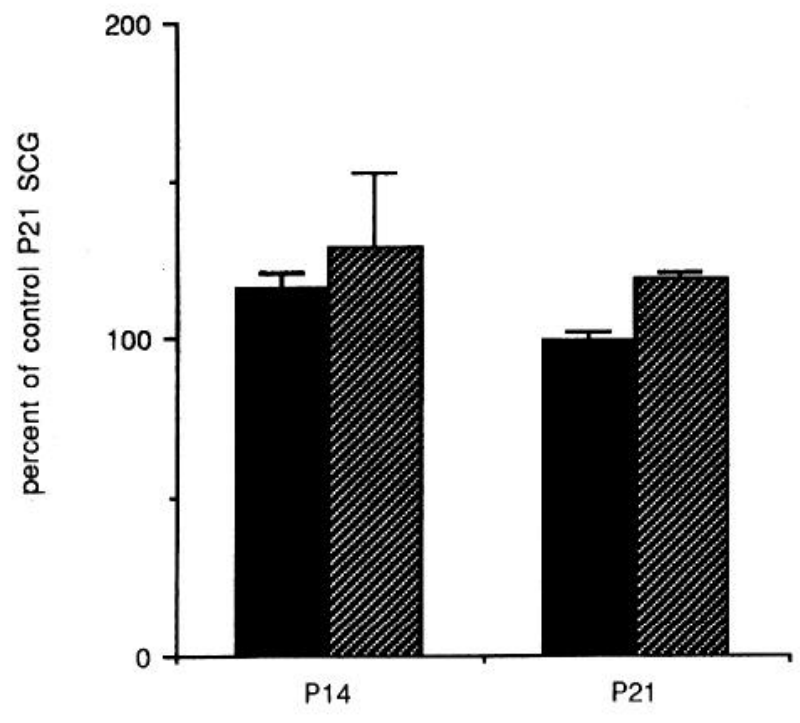

age

Figure 13. NPY-IR in SCG was not reduced following 6-OHDA treatment. The concentration of NPY-IR (pg NPY-IR/mg protein) in SCG extracts from 6-OHDA-treated animals (hatched bars) was not significantly different from that in extracts from control animals (solid bars) at P14 ( $t$ test, $p>0.05$ ). At P21 there was a small but significant increase in the concentration of NPY-IR in SCG extracts ( $t$ test, $p=0.005$ ). Extracts from both control and 6-OHDA-treated animals were assayed at the same time. Error bars represent SEM in one direction only. Three and Patterson, 1993). While CDF/LIF plays an important role in mediating the neuropeptide inductions observed in mature sympathetic neurons after axotomy (Rao et al., 1993), no roles in determining peptide phenotypes during development in vivo have yet been assigned either CDF/LIF or CNTF. In addition to these well-characterized differentiation factors, media conditioned by different tissues have distinct effects on neuropeptide expression by sympathetic neurons in vitro, suggesting that particular target tissues produce specific complements of peptide-inducing factors (Nawa and Patterson, 1990; Nawa and Sah, 1990). How many of these putative target-derived signals contribute to determining the repertoires of neuropeptide phenotypes in sympathetic neurons in vivo remains to be determined.

\section{References}

Anderson DJ (1986) A bipotential neuroendocrine precursor whose choice of cell fate is determined by NGF and glucocorticoids. Cell 47:1079-1090.

Anderson DJ (1989) The neural crest cell lineage problem: neuropoiesis? Neuron 3:1-12.

Anderson DJ (1993) Molecular control of cell fate in the neural crest: the sympathoadrenal lineage. Annu Rev Neurosci 16:129-158.

Anderson DJ, Carnahan J, Michelsohn A, Patterson PH (1991) Antibody markers identify a common progenitor to sympathetic neurons

\section{$\leftarrow$}

SCG extracts, made from ganglia from different animals, were assayed for all points except SCG from P14 6-OHDA-treated rats for which four extracts were assayed. 
and chromaffin cells in vivo, and reveal the timing of commitment to neuronal differentiation in the sympathoadrenal lineage. $J$ Neurosci 11:3507-3519.

Angeletti PU (1971) Chemical sympathectomy in newborn animals. Neuropharmacology 10:55-59.

Angeletti PU, Levi-Montalcini R (1970) Sympathetic nerve cell destruction in newborn mammals by 6-hydroxydopamine. Proc Natl Acad Sci USA 65:114-121.

Ball WD, Hand AR, Johnson AO (1984) Two independently regulated secretory systems within the acini of the submandibular gland of the perinatal rat. Eur J Cell Biol 33:112-122.

Ball WD, Hand AR, Johnson AO (1988) Secretory proteins as markers for cellular phenotypes in rat salivary glands. Dev Biol 125:265-279.

Bastiaensen E, de Potter W (1987) Enkephalin containing peptides in the peripheral sympathetic nervous system. Neurochem Int 11:313321.

Bhoola KD, Dorey G, Jone CW (1973) The influence of androgens on enzymes (chymotrypsin- and trypsin-like proteases, renin, kallikrein and amylase) and on cellular structure of the mouse submaxillary gland. J Physiol (Lond) 235:503-522.

Birch MP, Christie DL (1986) Characterization of the molecular forms of proenkephalin in bovine adrenal medulla and rat adrenal, brain, and spinal cord with a site directed antiserum. J Biol Chem 261: 12213-12221.

Black IB, Mytilineou C (1976) Trans-synaptic regulation of the development of end organ innervation by sympathetic neurons. Brain Res 101:503-521.

Bowers CW, Zigmond RE (1979) Localization of neurons in the rat superior cervical ganglion that project into different postganglionic trunks. J Comp Neurol 185:381-392.

Camden J, Martinez JR (1987) Na, K ATPase activity during early postnatal development of the rat submandibular gland. Experientia 43:570-572.

Cheung C (1989) Adrenal growth and ontogeny of adrenal substance $P$, enkephalins, and catecholamines in the ovine fetus. J Dev Physiol 12:77-84.

Clark DWJ, Laverty R, Phelan EL (1972) Long-Lasting peripheral and central effects of 6-hydroxydopamine in rats. $\mathrm{Br} \mathrm{J}$ Pharmacol 44: 233-243.

Coulombe JN, Nishi R (1991) Stimulation of somatostatin expression in developing ciliary ganglion neurons by the cells of the choroid layer. J Neurosci 11:553-562.

Coulombe JN, Schwall R, Parent AS, Eckenstein FP, Nishi R (1993) Induction of somatostatin immunoreactivity in cultured ciliary ganglion neurons by activin in choroid cell-conditioned medium. Neuron 10:899-906.

Coulter CL, Browne CA, McMillen IC (1990) The molecular weight profile of enkephalin-containing peptides in the sheep adrenal gland changes during development. Endocrinology 127:330-336.

Cutler LS, Chaudhry AP (1974) Cytodifferentiation of the acinar cells of the postnatal rat submandibular gland. Dev Biol 41:31-41.

Cutler LS, Christian CP, Bottaro B (1981) Development of stimulussecretion coupling in salivary gland secretory cells. Methods Cell Biol 23:532-545.

Davis TP, Hoyer GL, Davis P, Burks TF (1990) Proenkephalin A derived peptide $E$ and its fragments alter opioid contractility in the small intestine. Eur J Pharmacol 191:253-261.

Domeij S, Dahlqvist A, Forsgren S (1991) Enkephalin-like immunoreactivity in ganglionic cells in the larynx and superior cervical ganglion of the rat. Reg Peptides 32:95-107.

Epstein ML, Davis JP, Gellman LE, Lamb JR, Dahl JL (1988) Cholinergic neurons of the chicken ciliary ganglion contain somatostatin. Neuroscience 25:1053-1060.

Ernsberger U, Sendtner M, Rohrer H (1989) Proliferation and differentiation of embryonic chick sympathetic neurons: effects of ciliary ncurotrophic factor. Neuron 2:1275-1284.

Fann M, Patterson PH (1993) A novel approach to screen for cytokine effects on neuronal gene expression. J Neurochem 61:1359-1355.

Finch L, Haeusler G, Kuhn H, Thoenen H (1972) The recovery of vascular adrenergic nerve function in the rat after chemical sympathectomy with 6-hydroxydopamine. Br J Pharmacol 44:357P-358P.

Finch L, Haeusler G, Thoenen H (1973) A comparison of the effects of chemical sympathectomy by 6-hydroxydopamine in newborn and adult rats. Br J Pharmacol 47:249-260.

Friedin M, Kessler J (1991) Cytokine regulation of substance P ex- pression in sympathetic neurons. Proc Natl Acad Sci USA 88:32003203.

Gabella G (1976) Structure of the autonomic nervous system. New York: Wiley.

Garrett JR (1974) Secretory mechanisms of exocrine glands. New York: Academic.

Giloh H, Sedat JW (1982) Fluorescence microscopy: reduced photobleaching of rhodamine and fluorescein protein conjugates by $N$-propyl gallate. Science 217:1252-1255.

Hamano E, Yamazaki T, Saito M, Kawashima H, Ozeki T, Furuyama S (1989) Comparison of phosphofructokinases in submandibular glands of immature and adult rats. Comp Biochem Physiol 94B:697701 .

Henion PD, Landis SC (1990) Asynchronous appearance and topographic segregation of neuropeptide-containing cells in the developing rat adrenal medulla. J Neurosci 10:2886-2896.

Henion PD, Landis SC (1992) Developmental regulation of leucineenkephalin expression in adrenal chromaffin cells by glucocorticoids and innervation. J Neurosci 12:3818-3827.

Henion PD, Landis SC (1993) Modulation of the enkephalinergic phenotype of sympathetic neurons by hormonal and transynaptic mechanisms. J Neurobiol 24:1243-1251.

Hokfelt T (1991) Neuropeptides in perspective: the last ten years. Neuron 7:867-879.

Hokfelt T, Elfvin L, Schultzberg M, Fuxe K, Said SI, Mutt V, Goldstein M (1977) Immunohistochemical evidence of vasoactive intestinal polypeptide-containing neurons and nerve fibers in sympathetic ganglia. Neuroscience 2:885-896.

Howells RD, Kilpatrick DL, Bailey LC, Noe M, Udenfriend S (1986) Proenkephalin mRNA in heart. Proc Natl Acad Sci USA 83:19601963.

Jaim-Etcheverry, Zieher LM (1971) Permanent depletion of peripheral norepinephrine in rats treated at birth with 6-hydroxydopamine. Eur J Pharmacol 13:272-276.

Jarvi R, Helen P, Pelto-Huikko M, Hervonen A (1986) Neuropeptide Y- (NPY-) like immunoreactivity in rat sympathetic neurons and small granule containing cells. Neurosci Lett 67:223-227.

Kanagawa-Terayama $Y$, Wanaka $\Lambda$, Yamasaki $H$, Matsuyama $T$, Matsumoto M, Kamada T, Yanaihara C, et al. (1989) Immunocytochemical analysis of [Met5] enkephalin-Arg6-Gly7-Leu8 immunoreactive structures in the rat superior cervical ganglion. Brain Res 494:75-84

Katz DM, He H, White M (1992) Transient expression of somatostatin peptide is a widespread feature of developing sensory and sympathetic neurons in the embryonic rat. J Neurobiol 23:855-870.

Kilpatrick DL, Howells RD, Noe M, Bailey CL, Udenfriend S (1985) Expression of preproenkephalin-like mRNA and its peptide products in mammalian testis and ovary. Proc Natl Acad Sci USA 82:74677469 .

Kilpatrick DL, Borland K, Jin DJ (1987) Differential expression of opioid peptide genes by testicular germ cells and somatic cells. Proc Natl Acad Sci USA 84:5695-5699.

Kondo H, Yamamoto M, Yanaihara N, Nagatsu I (1988) Transient involvement of enkephalins in both sympathetic and parasympathetic innervations of the submandibular gland of rats. Cell Tissue Res 253: 529-537.

Landis SC (1990) Target regulation of neurotransmitter phenotype. Trends Neurosci 13:344-350.

Landis SC, Fredieu JR (1986) Coexistence of calcitonin gene-related peptide and vasoactive intestinal peptide in cholinergic sympathetic innervation of rat sweat glands. Brain Res 377:177-181.

Landis SC, Patterson PH (1981) Neural crest lineages. Trends Neurosci 4:172-175.

Landis SC, Siegel RE, Schwab M (1988) Evidence for neurotransmitter plasticity in vivo. II. Immunocytochemical studies of rat sweat gland innervation during development. Dev Biol 126:129-140.

Livett BG, Day R, Elde RP, Howe PRC (1982) Co-storage of enkephalins and adrenaline in the bovine adrenal medulla. Neuroscience 7:1323-1332.

Ludford JM, Talamo BR (1980) $\beta$-Adrenergic and muscarinic receptors in developing rat parotid glands. J Biol Chem 255:4619-4627.

Luebke JI, Wright LL (1992) Characterization of superior cervical ganglion neurons that project to the submandibular glands, the eyes, and the pineal gland in rats. Brain Res 589:1-14.

Martinez A, Padbury J, Chappell B, Habib D, Thio S, Burnell E (1991) 
Maturational changes in expression of enkephalin peptides in adrenal and extra-adrenal tissue of fetal and adult rabbits. Brain Res Bull 26: 935-940.

Martinez JR, Camden J (1986) Temporal dissociation in the ability of ouabain and furosemide to inhibit $\mathrm{K}^{+}$-transport in rat submandibular salivary gland slices at various postnatal ages. Arch Oral Biol 31:319-323.

Masu Y, Wolf E, Holtzmann B, Sendtner M, Brem G, Thoenen H (1993) Disruption of the CNTF gene results in motor neuron degeneration. Nature 365:27-32.

Moreira JE, Ball WD, Mirels L, Hand AR (1991) Accumulation and localization of two adult acinar cell secretory proteins during development of the rat submandibular gland. Am J Anat 191:167-184.

Nawa H, Patterson PH (1990) Separation and partial characterization of neuropeptide-inducing factors in heart cell conditioned medium. Neuron 4:269-277.

Nawa H, Sah DWY (1990) Different biological activities in conditioned media control the expression of a variety of neuropeptides in cultured sympathetic neurons. Neuron 4:279-287.

Nawa H, Nakanishi S, Patterson PH (1991) Recombinant cholinergic differentiation factor (leukemia inhibitory factor) regulates sympathetic neuron phenotype by alterations in the size and amounts of neuropeptide mRNAs. J Neurochem 56:2147-2150.

Patterson PH, Nawa H (1993) Neuronal differentiation factors/cytokines and synaptic plasticity. Cell 72:123-137.

Pittius CW, Kley N, Loeffler JP, Hollt V (1985) Quantitation of proenkephalin A messenger RNA in bovine brain, pituitary and adrenal medulla: correlation between $\mathrm{mRNA}$ and peptide levels. EMBO J 4:1257-1260.

Raaberg L, Nexo E, Mikkelsen JD, Poulsen SS (1988) Immunohistochemical localization and developmental aspects of epidermal growth factor in the rat. Histochemistry 89:351-356.

Rao M, Patterson PH, Landis SC (1992) Multiple cholinergic differentiation factors are present in footpad extracts: comparison with known cholinergic factors. Development 116:731-744.

Rao M, Sun Y, Escary J, Perreau J, Tresser S, Patterson P, Zigmond $\mathrm{R}$, et al. (1993) Leukemia inhibitory factor mediates an injury response but not a target-directed developmental transmitter switch in sympathetic neurons. Neuron, in press.

Rao MS, Landis SC (1990) Characterization of a target derived neuronal cholincrgic differentiation factor. Neuron 5:899-910.

Rao MS, Tyrrell S, Landis SC, Patterson PH (1992) Effects of ciliary neurotrophic factor (CNTF) and depolarization on neuropeptide expression in cultured sympathetic neurons. Dev Biol 150:281-293.

Redman RS, Sreebny LM (1970) Proliferative behavior of differentiating cells in the developing rat parotid gland. J Cell Biol 46:81-87.

Rohrer H (1992) Cholinergic neuronal differentiation factors: evidence for the presence of both CNTF-like and non-CNTF-like factors in developing foot pad. Development 114:689-698.

Rubin E (1985) Development of the rat superior cervical ganglion: ganglion cell maturation. J Neurosci 5:673-684.

Sahara N, Fukasawa KM, Fukasawa K, Araki N, Suzuki K (1981) Immunohistochemical localization of depeptidyl aminopeptidase (DAP)IV in the rat submandibular gland during postnatal development. Histochemistry 72:229-236.

Sasek CA, Zigmond RE (1989) Localization of vasoactive intestinal peptide- and peptide histidine isoleucine amide-like immunoreactivities in the rat superior cervical ganglion and its nerve trunks. J Comp Neurol 280:522-532.

Schneyer CA, Hall HD (1969) Growth pattern of postnatally developing rat parotid gland. Proc Soc Exp Biol Med 130:603-607.

Schotzinger RJ, Landis SC (1988) Cholinergic phenotype developed by noradrenergic sympathetic neurons after innervation of a novel cholinergic target in vivo. Nature 335:637-639.

Schotzinger R, Landis SC (1990) Acquisition of cholinergic and peptidergic properties by the sympathetic innervation of rat sweat glands requires interaction with normal target. Neuron 5:91-100.

Schotzinger R, Yin X, Landis SC (1994) Induction of a novel, target- appropriate transmitter phenotype following transplantation. $J$ Neurobiol, in press.

Schultzberg M, Hokfelt T, Terenius L, Elfvin L, Lundberg JM, Brandt J, Elde RP, et al. (1979) Enkephalin immunoreactive nerve fibers and cell bodies in sympathetic ganglia of the guinea-pig and rat. Neuroscience 4:249-270.

Shadiack A, Hart R, Carlson C, Jonakait G (1993) Interleukin-1 induces substance $P$ in sympathetic ganglia through the induction of leukemia inhibitory factor. J Neurosci 13:2601-2609.

Shida T, Ueda Y, Ishida-Yamamoto A, Senba E, Tohyama M (1991) Enkephalinergic sympathetic and parasympathetic innervation of the rat submandibular and sublingual glands. Brain Res 555:288-294.

Siegel RF (1989) I ocalization of neuronal mRNAs by hybridization histochemistry. Methods Neurosci 1:136-150.

Siegel RE, Iacangelo A, Park J, E. EL (1988) Chromogranin A biosynthetic cell populations in bovine endocrine and ncuronal tissues: detection by in situ hybridization histochemistry. Mol Endocrinol $2: 368-374$

Soinila J, Salo A, Uusitalo H, Yanaihara N, Happola O (1989) CGRPimmunoreactive sensory nerve fibers in the submandibular gland of the rat. Histochemistry 91:455-460.

Soinila J, Happola O, Yanaihara N, Soinila S (1991a) Immunohistochemical localization of [Met5]enkephalin and [Met5]enkephalinArg6-Gly7-Leu8 in sympathetic and parasympathetic neurons and nerve fibers projecting to the rat submandibular gland. Neuroscience 40:545-554.

Soinila J, Salo A, Uusitalo H, Soinila S, Yanaihara N, Happola O (1991b) Met5-enkephalin-Arg6-Gly7-Leu8-immunoreactive nerve fibers in the major salivary glands of the rat: evidence for both sympathetic and parasympathetic origin. Cell Tissue Res 264:15-22.

Spruce BA, Curtis R, Wilkin GP, Glover DM (1990) A neuropeptide precursor in cerebellum: proenkephalin exists in subpopulations of both neurons and astrocytes. EMBO J 9:1787-1795.

Srinivasan R, Chang WWL (1977) Effect of neonatal sympathectomy on the postnatal differentiation of the submandibular gland of the rat. Cell Tissue Res 180:99-109.

Stachowiak MK, Lee PHK, Rigual RJ, Viveros OH, Hong JS (1988) Roles of the pituitary-adrenocortical axis in control of the native and cryptic enkephalin levels and proenkephalin mRNA in the sympathoadrenal system of the rat. Mol Brain Res 3:263-274.

Stevens LM, Landis SC. (1988) Neurotransmitter plasticity in the sympathetic fibers which innervate the sweat glands after a delay. Dev Biol 130:703-720.

Stcvens LM, Landis SC (1990) Target influences on transmitter choicc by sympathetic neurons developing in the anterior chamber of the eye. Dev Biol 137:109-124.

Thoenen H, Tranzer JP (1968) Chemical sympathectomy by selective destruction of adrenergic nerve endings with 6-hydroxydopamine. Arch Exp Pathol Pharmakol 261:271-288.

Tranzer JP, Thoenen H (1968) An electron microscopic study of selective, acute degeneration of sympathetic nerve terminals after administration of 6-hydroxydopamine. Experientia 24:155-158.

Tyrrell S, Landis SC (1994) NPY and VIP expression in sympathetic neuroblasts and subsequent regulation of neuropeptide expression. $\mathrm{J}$ Neurosci, in press.

Watanabe M, Yanaihara N, Kondo H (1991) Partial down-regulation at post-transcriptional level of the gene expression for preproenkephalin in the superior cervical ganglion of the maturing rat. Dev Brain Res 59:113-116.

Yamashina S, Barka T (1974) Peroxidase activity in the developing rat submandibular gland. Lab Invest 31:82-89.

Yoshikawa K, Williams C, Sabol SL (1984) Rat brain preproenkephalin mRNA. J Biol Chem 259:14301-14308.

Zacharatos DT, Vasak EZ, Cheng ESP, van Lennep EW, Morris BJ (1983) Immunohistochemistry of tonin in rat submandibular gland during development, lactation and secretion. Histochemistry 79:433442. 